\title{
Gastrointestinal Lymphatics in Health and Disease
}

\author{
J.S. Alexandera, Vijay C. Gantaa ${ }^{a}$ P.A. Jordan ${ }^{b}$, and Marlys H. Witte \\ aLouisiana State University Health Sciences Center-Shreveport, Molecular and Cellular \\ Physiology \\ bLouisiana State University Health Sciences Center-Shreveport, Gastroenterology and \\ Hepatology \\ cUniversity of Arizona, Department of Surgery
}

\section{Abstract}

Lymphatics perform essential transport and immune cell regulatory functions to maintain homeostasis in the gastrointestinal (GI) system. Although blood and lymphatic vessels function as parallel and integrated systems, our understanding of lymphatic structure, regulation and functioning lags far behind that of the blood vascular system. This chapter reviews lymphatic flow, differences in lymphangiogenic and hemangiogenic factors, lymphatic fate determinants and structural features, and examines how altered molecular signaling influences lymphatic function in organs of the GI system. Innate errors in lymphatic development frequently disturb GI functioning and physiology. Expansion of lymphatics, a prominent feature of GI inflammation, may also play an important role in tissue restitution following injury. Destruction or dysregulation of lymphatics, following injury, surgery or chronic inflammation also appears to exacerbate GI disease activity and morbidity. Understanding the physiological roles played by GI lymphatics is essential to elucidating their underlying contributions to forms of congenital and acquired forms of GI pathology, and will provide novel approaches for treatment of these conditions.

\section{Keywords}

Interstitial fluid; intestinal; lymphatics; inflammation; vascular endothelial growth factors-C, D; VEGFR-3; Prox1; SOX18; FOXC2; lymphedema

\section{Introduction}

The intense research focus on blood vascular biology and angiogenesis of the past quarter century has far exceeded that of lymphatic biology. Until very recently, the lymphatic vasculature received much less attention than blood vessels. This oversight reflects historical difficulties in visualizing lymphatics, a lack of appreciation for their subtlety of function, and therefore, less emphasis on developing methods and markers to study them. Currently, lymphatic biology is experiencing an enormous renewal in interest, and the importance of lymphatics in disease is gaining recognition outside of the fields of lymphedema and cancer

(C) 2009 Elsevier Ireland Ltd. All rights reserved.

Corresponding author at: Molecular and Cellular Physiology, LSU Health Sciences Center in Shreveport, LA, 1501 Kings Highway, Shreveport, LA. Tel: (318)-675-4151, Fax: (318)-675-4156, jalexa@1suhsc.edu (J.S. Alexander).

Publisher's Disclaimer: This is a PDF file of an unedited manuscript that has been accepted for publication. As a service to our customers we are providing this early version of the manuscript. The manuscript will undergo copyediting, typesetting, and review of the resulting proof before it is published in its final citable form. Please note that during the production process errors may be discovered which could affect the content, and all legal disclaimers that apply to the journal pertain. 
biology, to now include acute and chronic inflammation. The gastrointestinal (GI) tract is an organ system which critically depends on adequate lymphatic functioning and defects in lymphatics during embryonic development are manifested as 'chylous' intestinal disturbances.

Historically, lymphatic (chylous or 'white blood') vessels were independently 'discovered' several times in early Egypt, China and Greece, Hippocrates (460-370 BC) is most often credited with their discovery in the treatise 'Peri adenôn' [1]. Hippocrates coined the term for gland ('adenes'), and correctly designated lymphatic roles in interstitial fluid balance: ('...if moisture is moderate, there is no fluid accumulation in any part of the body because lymph glands drain off such liquid'); he also was the first to understand lymphatic roles in inflammation [2]. With respect to GI lymphatics, Herophilus (335-280 BC), Erasistratus (310-250 BC) and Ruphus (98-117 A.D.) were among the first to mention mesenteric lymphatic vessels and glands of the small intestine. Later Galen (129-199 AD) also described intestinal lacteals (in pigs and apes). Later, Gaspar Asseli (1581-1626) of Milan, described and illustrated lymph flow in 'chyliferous vessels of the post-prandial dog', posthumously published in 1627, a year before William Harvey proved the circulation of blood. Olaf Rudbeck (1630-78) in Sweden later identified connections between blood and lymphatic systems, discovered the thoracic duct and found lymphatics of the liver, colon and esophagus. Rudbeck also realized the importance of lymphatics in edema and ascites [3]. However, although the normal functions and pathophysiology of the blood microcirculation in the gastrointestinal system have been studied in some detail, [4-6] fewer studies have examined GI lymphatic flow, disturbed lymphatic vessel structure and lymphatic flow in GI disease. In this review, we review lymphatic structure and function in the different GI organs, examine links between post-natal lymphatic disturbances in gastrointestinal disease and consider how inherited defects in lymphatic patterning and development interfere with GI function. Other chapters in this series will describe in detail the current understanding of the molecular and physical mechanics of lymphatic pumping (and are only mentioned superficially here.)

\section{Lymph flow}

Nutrient and fluid absorption in the GI tract requires lymphatic networks to both regulate interstitial fluid balance and transport lipids. GI lymphatics also fulfill important mucosal immune functions in acquired immunity and tolerance because the GI absorptive surface is immense $\left(>200 \mathrm{~m}^{2}\right)$ and densely colonized by bacterial commensals $\left(\sim 10^{14}\right.$ bacteria). Total lymph formation in humans is approximately $1-4$ liters/day, most of which $(>50 \%)$ is formed in the GI tract. Lymph flows vary widely in the different organs of the human GI system [7]; gastric lymph flow (LF) is normally $~ 0.06 \mathrm{ml} / \mathrm{min} / 100 \mathrm{~g}$, small intestinal LF is $\sim 0.045 \mathrm{ml} / \mathrm{min} / 100 \mathrm{~g}$, large intestine LF is $\sim 0.015 \mathrm{ml} / \mathrm{min} / 100 \mathrm{~g}$. Salivary gland LF is $\sim 0.14$ $\mathrm{ml} / \mathrm{min} / 100 \mathrm{~g}$, pancreas LF is $\sim 0.009 \mathrm{ml} / \mathrm{min} / 100 \mathrm{~g}$ and liver LF is $\sim 0.05 \mathrm{ml} / \mathrm{min} / 100 \mathrm{~g}$. Interstitial fluid formed in tissues is collected in initial lymphatics and is pumped by 'lymphangions', the contractile unit of lymphatics, consisting of a lymphatic segment bounded by two unidirectional valves and driven by contraction of specialized smooth muscle. Changes during normal physiology, e.g. those produced by feeding (particularly, after fat-containing meals), greatly stimulate GI lymph flow in general and within the mesentery in particular; a phenomenon first identified in 1622 by Gasparo Aselli in well-fed dogs (and executed convicts.) In addition to feeding, lymph flow is also elevated by acute and chronic inflammation and by intestinal obstruction [8]. Besides 'extrinsic' factors governing lymph propulsion (peristaltic muscular contraction, abdominothoracic 'pumping'), 'intrinsic' factors also regulate pumping of mesenteric lymphangions.

Lymphatic pumping is increased by cholecystokinin (CCK), glucagon, endothelin, bradykinin, substance-P, $\mathrm{PGE}_{1}, \mathrm{PGF}_{2}-\alpha$, serotonin, histamine, $\alpha$-adrenergic agonists, 
dopamine, ATP and lipopolysaccharide. Conversely, pumping is diminished by anti-diuretic hormone (ADH/vasopressin), vasoactive intestinal peptide (VIP), $\mathrm{PGI}_{2}$ (prostacyclin), acetylcholine and reactive oxygen metabolites $\left(\mathrm{H}_{2} \mathrm{O}_{2}, \mathrm{O}_{2}{ }^{--}\right)$[9-11]. Oxygen tension in lymphatics is similar to that in venous blood $(\sim 8-35 \mathrm{~mm} \mathrm{Hg})[12 ; 13]$. This relatively low $\mathrm{O}_{2}$ level may help maintain lymphatic phenotype, and is sufficient to support lymphangion pumping activity [14], but may render lymphatics susceptible to injury during ischemic stress or reperfusion. (More detailed analyses of factors and mechanisms controlling lymphatic propulsion are described in chapters in this issue and previous studies by Muthuchamy, Von derWeid and by Zawieja et al., [10;11;15-21].

\section{Lymphatic endothelial cells}

Developmentally, lymphatic endothelial cells (LECs) are derived from venous progenitor cells [22], and differ from blood endothelial cells (BECs) in their expression of 'lymphatic' markers including vascular endothelial growth receptor-3 (VEGFR-3, also known as Flt-4), the Prospero homeobox-1 fate determining transcription factor, Prox-1 [23], lymphatic vascular endothelial hyaluronan (LYVE-)1, podoplanin, secondary lymphoid tissue chemokine/ chemokine ligand-21 (SLC/CCL21), $\beta$-chemokine receptor D6 [24], matrix G1a protein, the extracellular matrix protein (MFAP3), reelin [25], $\alpha 1$ and $\alpha 9$-integrins, desmoplakins I and II, cadherin-13, ZO-2, plakophilin, macrophage mannose receptor-I, $\alpha$ actinin-2 associated (Lin11, Isl-1 \& Mec-3) LIM protein , p57 kip2, tissue inhibitor of metalloproteinase-3 (TIMP-3), and stromal cell-derived factor 1-b (SDF-1b) [22;26]. Some specialized BEC (e.g., 'high' endothelial venules and liver sinusoidal endothelium) also express LYVE-1 [27-29].

BEC-specific markers may include pathologische anatomie Leiden-endothelium/ plasmalemmal vesicle-1 (PAL-E/PV-1) [30], $\alpha 5$ - and $\beta 5$-integrin, ICAM-1, N-cadherin, claudin-7, vinculin, CD34, CD44, endoglin/CD105, adducin- $\gamma$, interleukin- 8 , monocyte chemotactic protein-1 (MCP-1), collagens 8A1, 6A1 and 1A2, laminin- $\gamma 2$, uPA (urokinase plasminogen activator), matrix metalloproteinase-1 (MMP-1), signal transducer and activator-6 (STAT6), UFO/axl and CXCR4 [26;31]. P- and E-selectins have been reported in both BEC and LEC and are not reliable distinguishing markers.

Many of these transcripts are suppressed in LECs by Prox-1 [22;26;32] that induces lymphatic programming, while silencing BEC transcripts. IL-3 indirectly regulates LEC fate determination by regulating Prox-1 activity, and induces expression of LEC markers LYVE-1 and podoplanin in BEC [33]. Similarly, the transcription factor SOX18 (SRY, sex determining region Y, box 18) binds to and activates the Prox-1 promoter [34]. Mutations in SOX18 are linked with hypotrichosis-lymphedema-telangiectasia syndrome (HLTS) [35] associated with post-natal alopecia, permanent dilation of small blood vessels, and focal red lesions.

Prox-1 controls lymphatic differentiation from venous progenitors [36] through several mechanisms. By inducing $\alpha 9$ integrin expression [37], Prox1 initiates integrin-dependent motility. Integrin a9 deficient mice show congenital chylothorax [38]. Prox 1 also drives VEGFR-3 expression which enables LEC to respond to (and migrate towards) VEGFR-3 ligands such as VEGF-C and D. VEGF-C binding to VEGFR-3 [26] appears necessary for prenatal lymphatic patterning; VEGF-D also binds to VEGFR-3 but in embryos, its activity is dispensable. However, VEGF-D participates in post-natal control of lymphangiogenesis and angiogenesis.

The organization and barrier function of LECs is regulated by several factors including adrenomedullin (AM). AM organizes ZO-1 and VE-cadherin at the cell membrane and decreases lymphatic permeability [39]. However, AM-regulated lymphatic exchange is 
controversial. AM is necessary for vascular development [40], induces lymphangiogenesis, and plays a major role in attenuating lymphedema [41]. AM also selectively enhances ERK1/2 signaling in LECs and drives LEC proliferation. These effects are mediated by Prox-1 activation of AM [42;43] through its receptor CALCRL (calcitonin-receptor like receptor) interacting with RAMP2 [43]. Interestingly, CALCRL is a Prox-1-dependent transcript and AM, CALCRL and RAMP2 knockout mice exhibit lymphedema with perinatal mortality.

It is striking that LECs in several tissues (e.g. bladder, GI tract) constitutively express high levels of the transcription factor NF- $\kappa B$ [44]. In BECs, NF- $\kappa B$ signaling is often associated with inflammatory/angiogenic cascades, which is particularly active in venous rather than arterial endothelium [45]. Persistent NF- $\mathrm{\kappa B}$ expression by LECs may represent an important downstream signal from VEGFR-3 that also induces VEGF-C transcription. At least one report [46] suggests that lymphatic defects and a lymphedematous phenotype associated with VEGFR-3 missense mutations may involve dysregulated downstream NF- $\kappa B$ signaling. The persistent NF- $\mathrm{KB}$ expression in LECs has also been suggested as a potential therapeutic target for controlling growth of tumor lymphatics [47].

\section{Separation of blood and lymphatic circulations}

Two important factors, the 'Syk' kinase and its target SLP-76, expressed by bone marrow derived endothelial precursors, indirectly provide signals for the separation of blood and lymphatic vascular circuits [48;49]. VEGFR-3 signaling may also be suppressed through Spreds- 1 and 2 regulators of LEC development and blood-lymph separation [50]. Bäckhed et al., [51] report that separation of blood and lymphatic vessels in the small intestine is also mediated by fasting-induced adipose factor (FIAF, angiopoietin-like factor 4) through induction of Prox-1 [51]. FIAF ${ }^{-1-}$ mice have fused blood and lymphatic vessels with perinatal lethality. FIAF is increased in adipose tissue during fasting, hypoxia and in response to thiazolidines [52] and decreased by fat feeding and reduced gut Bifidobacteria colonization of the gut [53]. The role of FIAF in Prox-1 regulated lymphatic homeostasis may be important in the Prox-1 $1^{-/-}$induced insulin resistance and obesity (see below) [54].

Fu et al. [55] reported that mucin-type O-glycans expressed by endothelial (and hematopoietic) cells maintain essential separation of blood/lymphatic circuits, particularly in the intestine. This depends on the C1galt1 gene and reflects O-glycan modification of podoplanin. C1galt1 O-glycan deficiency leads to blood/lymphatic misconnections and to fatty liver disease. Ichise and Ichise (2009) also report a role for phospholipase C- $\gamma 2$ in blood/lymphatic separation [56].

\section{Additional factors regulating lymphatic patterning}

While not specific to lymphatics, Ephrin b2 participates in forming lymphatic collecting ducts and capillaries from an existing lymphatic plexus, and Ephrin b2 deletion in both BECs and LECs leads to vessel malformation and hemorrhage. Also, LEC-specific Ephrin b2 ${ }^{-1-}$ mice exhibit lymphatic defects resembling hereditary lymphedema [52]. Notch signaling positively regulates both Ephrin b2 and VEGFR-3 expression, and both Notch 1 and 4 are expressed in murine LECs. It has been suggested that Notch pathway may play an important role in lymphatic patterning and structural integrity [57]. Other gene knockouts seen to produce lymphatic phenotypes include Elk (Ets-like gene 1)(causes an early chylothorax with dilated thoracic lymphatic vessels, but lacking lymphedema), podoplanin, (produces a hereditary lymphedema seen in the skin, legs and neck mediated by atypical lymphatic networks, and intestinal lymphangiectasia), [38]. 
LECs in initial lymphatics are thinner than BECs, with less basal lamina than in BECs and without fenestrations. However, complexes as large as chylomicrons $(120-620 \mathrm{~nm}$, avg. $170 \pm 50 \mathrm{~nm}$ ) regularly pass across and into the lymphatic lumen [58]. In place of fenestrations, initial LECs are joined at 'oak-leaf' shaped 'flaps' by discontinuous 'button'like punctae that may act as ' 1 ' junctions at the level of collecting lymphatics [59]. Both of these structural features contain vascular endothelial (VE)-cadherin, occludin, claudin-5, zonula occludens (ZO)-1 protein, junctional adhesion molecule-A (JAM-A) and endothelial specific molecule-1 (ESM-1). Increased interstitial fluid pressure (e.g. in inflammation), transfers tension from collagen in the extracellular matrix (ECM) to oxytalan, elastin and elaunin fibers to lymphatics, opening the junctions to increase fluid collection [60-62].

The development of the smooth muscular investment of lymphatics which begins during embryogenesis may continue post-natally [63;64]. Lymphatic plexuses expressing both Ephrin b2 and b4 give rise to vessels that are Ephb4 $4^{-} / E p h ~ b 2^{+}$and become invested with smooth muscle, to become collecting ducts. Eph b2 is not as abundant in lymphatic capillaries. Further, hypoxia also induces Notch 4, down-regulates VEGFR-2 and increases VEGFR-3, events driving further lymphatic specification. Angiopoietin-2 (Ang-2) a regulator of blood and lymphatic development and of inflammation [65] is also expressed in LECs [26;62]. Ang- $2^{-/-}$mice exhibit lymphodysplasia particularly in the intestine [66] and Ang $2^{-I-}$ mice may be a model to investigate roles of lymphatics in the GI tract. The FoxC2 forkhead transcription factor is important in lymphatic valve development. FoxC2-deficient mice fail to develop both valves and smooth muscle investment and these mice are model of lymphedema distichiasis (LDS) [67]. Neuropilin-2 (NRP-2), a co-receptor for VEGF receptors, interacts with VEGFR-3 and regulates lymphatic development [47;68]. FoxC2 also regulates Notch pathway, Delta-like 4 (Dl14), CXCR4, integrin $\beta 3$, and Ang-2 [69]. We have found that Ang- $2^{-/-}$mice, a model of intestinal lymphatic hypoplasia are more susceptible to developing experimental colitis, despite reduced leukocyte infiltration and angiogenesis [70] supporting a protective role of lymphatics against gut inflammation.

In adults, lymphangiogenesis can occur by expanding existing lymphatic networks, from venous structures [71] or recruitment of macrophage-like lymphatic progenitors [72;73]. These processes are regulated by members of the VEGF family $(-\mathrm{C}, \mathrm{D})$, environmental and biomechanical forces. The pattern of interstitial flow in tissues is an important determinant of lymphatic patterning during wound healing [74;75] and may be MMP $(-2 / 3)$ dependent [76]. MMP-9 also participates in lymphatic regeneration and wound healing and MMP- ${ }^{-/-}$ mice show persistent post-surgical lymphedema [77]. Nitric oxide bioavailability can also indirectly modulate lymphatics by regulating the levels and ratios of growth factors in lymphangiogenesis [74;78;79]. Several factors like cytokines and LPS induce an inflammatory lymphatic phenotype [80-84]. TGF- $\beta$ is also a negative regulator of lymphatics and lymphangiogenesis [85] and prevents lymphatic regeneration after injury [86].

\section{Lymphatics and leukocyte trafficking}

Lymphatics are essential conduits for the re-circulation of lymphocytes, which pass from blood to tissues and then to lymph nodes (or accessory lymphoid tissues) before returning to the circulation. Like BECs, LECs express adhesion molecules and chemokines that support interactions between LECs and activated immune cells. SLC/CCL21, a ligand for CCR7 receptor is induced on LECs in response to several stimuli (e.g., LPS and VEGF-C) [87]. Increased LEC expression of SLC/CCL21 is found in mesenteric lymph nodes in Crohn's disease, but not those in ulcerative colitis [88], and mediates the immune retention of CCR7 ${ }^{+}$naïve, Th1 T-cells and dendritic cells. SLC/CCL21 is also increased in LECs in the pancreas in non-obese diabetes [89]. CCL20 and CCL21 expressed by LECs also mediates 
CCR $6^{+} / 7^{+}$leukocyte trafficking as part of lymphatic immune surveillance [90]. Hyaluronan expressed by lymphatics may also direct leukocyte trafficking into lymphatics, and LYVE-1 interactions with hyaluronan may influence this event.

\section{Lymphatics in different GI organs}

\section{Tonsils}

Tonsils are not part of the GI system, but are important secondary $\left(2^{\circ}\right)$ lymphoid organs within the mucosal associated lymphoid tissue (MALT). The tonsils form a lymphoid tissue 'ring' (Waldeyer's ring) at the base of the tongue and throat providing immune surveillance for the esophagus and trachea [64]. The tonsillar mucosa has an abundant lymphatic supply, but appears to lack afferent lymphatics. Tonsillar lymphatics drain to the medial retropharyngeal lymph node, leading to the jugular lymph duct then entering the blood circulation at the brachiocephalic junction. When obstructed, tonsillitis (known as tonsillar lymphangitis) requires surgical excision.

\section{Salivary glands}

Salivary glands have the highest rate of lymphatic flow per gram of tissue of all regions studied in the GI tract [91]. The function of salivary glands is to support saliva formation by regulating interstitial fluid composition during salivary secretion [92]. Two types of lymphatics are described in the salivary capsules: one is associated with salivary ducts, and a second that forms networks closely associated with salivary blood vessels. Hata et al. [93] have reported that expression of the lymphatic marker podoplanin not found within the acini of the parotid, but could be demonstrated in the submandibular and sublingual glands. The number of podoplanin ${ }^{+}$staining lymphatics is greater in the sublingual than in submandibular glands, and podoplanin ${ }^{+}$lymphatics were found in basal regions of ducts in all major salivary glands. Salivary glands secrete VEGF-A [94;95] into saliva, increases flow and permeability in salivary blood vascular capillaries. In this manner, VEGF-A has been theorized to enhance interstitial fluid delivery. VEGF-A may support growth and development of blood and lymphatic vessels after epithelial injury [94]. VEGFs may thus exert a trophic effect on GI epithelium restoring epithelial integrity after injury, a conclusion supported by findings that recurrent apthous ulcers are correlated with low salivary VEGF-A [96].

\section{Esophagus}

There are considerable interconnections among the three lymphatic drainage domains within the esophagus. In the upper third of the esophagus, lymphatics drain to the deep cervical lymph nodes. Lymphatics of the mid esophageal drain to the superior and posterior mediastinal lymph nodes [97]. The lower third of the esophageal lymphatics follows the left gastric artery to the gastric and celiac lymph nodes. Esophageal lymphatics conduct interstitial fluid (ISF) but, more specialized functions of esophageal lymphatics are not known. In cancer, however, esophageal lymphatics contribute to the metastatic spread of esophageal tumor cells. In Barrett's esophagus, lymphatics expand during the transition to adenocarcinoma [98] and metastasis.

\section{Stomach}

Lymphatic flow in the stomach begins within the initial lymphatic sinuses near the pyloric glands. These fuse to link lymphatic networks between the muscularis mucosa and the submucosa [91]. In rats, initial lymphatics in the mucosa are limited to the deeper layers, near the muscularis mucosa [99]. Submucosal gastric lymphatics have also been demonstrated below the muscularis mucosa with few if any vessels found in the muscularis externa [100]. Humans also show gastric mucosal lymphatics in the deep mucosa close to 
the muscularis mucosa, but the upper two thirds of the mucosa is normally devoid of lymphatics [101;102]. Gastric lymphatics are designated by the arteries they follow and often drain to lymph nodes along these arteries. The final lymph nodes collecting stomach lymph are the pre-aortic (also 'celiac') nodes found in front of the aorta around the celiac trunk as it arises from the abdominal aorta. Lymph from the gastric and duodenal regions is collected from gastric, gastro-epiploic, pancreaticosplenic, pyloric and hepatic nodes that pass lymph into the celiac nodes, intestinal lymph trunks, union of abdominal lymph trunks and finally, to the thoracic duct.

There is a rapid post-natal expansion of submucosal and subserosal lymphatics in the gastric wall in response to digestive signals, an event evident in the posterior aspect / lesser curve of the stomach. NF-kB-lacZ histochemistry reveals an abundant lymphatic network in the adult duodenum [44]. Another histochemical marker of lymphatics, 5'-nucleotidase, also demonstrates an extensive lymphatic network with valves within these layers. In severe atrophic gastritis, the mucosal layer becomes thinner, and initial lymphatics can be seen proportionately closer to the surface epithelium [103].

\section{Small intestine (SI)}

Small intestinal villar lacteals are found in the center of each villus $\sim 50 \mu \mathrm{m}$ from the basement membrane [104-106] (Fig. 1a). Lymphatic lacteals inside intestinal villi carry lipid-enriched filtrates into these lymphatic plexuses. The networks formed by the jejunal and ileal lymphatic plexuses are known as the peri-glandular and sub-mucosal plexuses. Jejunal and ileal lymph drains from mesenteric nodes to celiac nodes, to intestinal lymph trunks, the union of abdominal lymph trunks and then to the thoracic duct. Intestinal lymphatics are the central conduit for clearing fluid, plasma proteins and blood cells that enter the intestinal interstitium from the blood playing dominant roles in the maintenance of gut homeostasis. Small intestine lymphatics efficiently transport absorbed lipids which are packaged and released by enterocytes in the small bowel [107]. Kim et al. showed that during embryogenesis small intestine lymphatics are formed by branching and extending of mesenteric lymphatics, rather than from intestinal mesoderm [108]. Although this process also depends on LYVE- $1^{+}$macrophages which activate VEGFR-3, LYVE-1 knockout (KO) mice have no apparent phenotype [109] suggesting that redundant pathways may substitute for LYVE- $1^{+}$macrophages. Intestinal lymphatics also remove water that enters the mucosal interstitium from epithelial electrolyte transporters [110]. The relative contributions of intestinal lymphatics to fluid clearance along the length of the intestine varies, changing with local organ function, the amount of lymphatic density in each segment and may also vary by species [111]. As an example, the size, density and interstitial fluid clearance capacity of the small intestinal lymphatic network is much higher than that of the colon. Further, while the central lacteals of small intestinal villi usually lie in close proximity ( $\sim 50$ $\mu \mathrm{m})$ to the epithelium thereby facilitating clearance of absorbed water, lymphatics in the colon originate deeper in the mucosa $(300-400 \mu \mathrm{m}$ from the mucosal epithelium) and exhibit a more extensive network in the submucosal layer [112]. The lymphatic system in the small intestine has components within the mucosa, submucosa and muscular layers. Fukushima et al., [113] have described central lacteals within the intestinal villus in the rat starting as blind-ended 'cul-de-sacs' merging into lymphatic sinuses which connect with the submucosal network and extend through the muscular layer. Submucosal and muscular lymphatics merge to create collecting lymphatics that carry lymph from the SI to the mesentery. Although valves have been reported between the mucosal and submucosal lymphatic networks [114], Benoit and Zawieja [111] suggest that these may be only weakly functional since dye injected into the submucosal layer can later be visualized in the mucosal layers. A layer of lymphatics which apparently lacks valves is found between the circular and longitudinal external muscular layers. Lee and Duncan [115] found that when 
venous outflow from the jejunum is blocked, absorbed fluid is diverted to the lymphatics, a process which may be important in several forms of intestinal inflammation.

\section{Large intestine}

Unlike the small intestine, the large intestine lacks lymphatic lacteals but is well supplied with lymphatic vessels (Fig. 1b). In rabbits, blood capillaries are found just below the epithelial layer and the lymphatic capillary network is arranged horizontally and closer to the muscularis mucosa [116]. In the dog, Hirashima et al., [117] and Hirai et al., [118] reported a dual layer network of 'shallow' lymphatic channels, one just under the capillary networks-under the mucosal surface and a deeper network above the muscularis mucosa. Some lymphatic capillaries also run parallel and vertically to the crypts of Lieberkuhn. The highest densities of lymphatic networks were found in the submucosa. Submucosal lymphatic vessels run parallel to blood vessels and have well-defined valve structure. Blind lymphatic projections arise from the networks surrounding the crypts. Lymphatic capillaries are larger in diameter than blood vessels. In dogs and cats, lymphatic vessels passing through the muscularis mucosa have valves. Lymph formed within the colon is collected in the colic nodes, and then passes to both superior and inferior mesenteric nodes, to the celiac nodes, the intestinal lymphatic trunks, the union of abdominal trunks and the thoracic duct. Surgical interruption of lymphatics results in the development of colon edema, which can either be reversed by the growth of collaterals (may take weeks) or may be permanent. One important consequence of the anatomic differences between the small intestine and the colon is a lower lymphatic capacity to clear ISF in the colon. This difference in ISF clearance significantly affects lymphatic immune cell clearance along the length of the intestine. The higher density of lymphoid tissues in the more distal segments of the intestine may indicate a greater participation of lymphatics in immune transport function in the distal small bowel and colon. As an example, in the rat, $\sim 2-5$ million lymphocytes enter intestinal lymphatics/ $\min$ (calculated as: lymphocytes $/ \mathrm{ml}$ in lymph $\times$ lymph flow) [91]. However, the number of lymphocytes found in lymph draining intestinal segments with Peyer's patches is $\sim 10$-fold greater than that measured in proximal gut segments devoid of lymphoid tissue [119]. These capacities of lymphatics to clear fluid and immune cells from the gut underscore the critical importance of the lymphatic vascular system in the maintenance of normal gut integrity and function. Several experimental studies [120-123] imply that insufficient gut lymphatic functioning will significantly exacerbate disease. Other essential functions of lymphatics are accomplished in lymph nodes, where bacteria and other pathogens are filtered and phagocytosed, to present antigens for acquired immunity. Large influxes of pathogens can overwhelm this system. Some pathogens (Yersinia, Epstein-Barr Virus) actually replicate within lymph nodes [124]. Once lymph borne pathogens (e.g. M. Tuberculosis, Corynebacterium, Staph. pyogenes, Micrococcus, Clostridia, E. coli, Aerobacter, Proteus, Candida and Chlamydia) pass beyond nodal barriers, their entry into the bloodstream produces serious consequences (e.g. sepsis) and systemic infections [125].

\section{Gut associated lymphoid tissues}

Peyer's patches (PPs) and mesenteric lymph nodes (MLNs) are secondary lymphoid organs associated with the intestine and GI tract [64]. Organization and development of secondary lymphoid organs may depend on factors such as lymphotoxins $\alpha \beta$, [126] [127]. While mesenteric lymph nodes receive antigen from lymphatic vessels in the mesentery, Peyers' patches lack afferent lymphatics and acquire antigen directly through cells within the mucosa, e.g., epithelium, M-cells and dendritic cells.

\section{Liver}

Lymph formed in the liver is a major contributor to total lymph flow with as much as $50 \%$ of total lymph being from hepatic origin. In the liver, lymph is collected by two pathways: a 
main right lobar path, and an accessory, left lobe path [128]. Hepatic lymph entering the space of Disse collects in lymphatic capillaries associated with the portal triads. Lymph in the space of Disse (peri-sinusoidal) drains to deep lymphatics in the hepatic parenchyma associated with portal triads (Fig. 2). Comparini described three types of liver lymphatic vessels [129]: portal tractal, hepatic venous and capsular vessels. In the liver, initial lymphatic capillaries containing valves are located in interlobular connective tissue and run parallel to blood vessels. These lymphatics become more clearly associated with arterial branches as larger divisions of the portal tract are examined. Intrahepatic lymphatic vessels are also found associated with branches of hepatic veins, but these are apparently not as abundant. Lymphatics are also present in the fibrous capsule of the liver. The liver capsule also contains superficial lymphatic vessels. Hepatic lymph is drained by deep and superficial lymphatics from the anterior surface face merging to deliver lymph to the 'porta hepatis' (transverse fissure), the hepatic and celiac nodes, right intestinal lymph trunk, union of abdominal lymph trunks and lastly, the thoracic duct. The $2^{\text {nd }}$ lymphatic drainage route is from the posterior face of the liver leading to the phrenic and posterior mediastinal nodes before entering the thoracic duct. Liver sinusoidal endothelial cells lack basal lamina and are fenestrated allowing bulk fluid and protein passage to the space of Disse located between the endothelium and hepatocytes, forming hepatic lymph. Both sinusoidal and lymphatic endothelial cells express a lymphatic marker LYVE-1 [28]. Interestingly, reelin, another LEC specific marker is found in the 'Ito' cells of the liver [25]. Heath and Lowden [130], showed that the only true lymphatic vessels in the hepatic acinus are in the portal tracts. Lymphatic vessels $<25 \mu \mathrm{m}$ diameter form a periportal venular network and are closely associated with the limiting plate of hepatocytes. The perisinusoidal space of Disse is contiguous with the interstitial space of the portal tracts at the origin of the sinusoids. Interstitial fluid derived from the sinusoids flows along this perisinusoidal space of Disse to enter portal tracts near the portal venules. This fluid then enters the small lymphatics adjacent to those venules which then merge with larger vessels suited near hepatic arterioles and bile ducts. The hepatic portal tract lymphatics drain fluid from the interstitial space, and are continuous with the perisinusoidal space of Disse where sinusoids emerge from the portal tract.

If liver sinusoidal pressure increases above normal $(\sim 3-5 \mathrm{~mm} \mathrm{Hg})$, lymph formation also increases. If sinusoidal pressure climbs far above normal [131], lymph can weep from the surface of the liver and accumulate in the abdomen as ascitic fluid. Splanchnic hypertension also greatly increases intestinal lymphatic flow. Fluid filters into the peritoneum as ascites through the diaphragmatic openings and into pleural cavities via 'lymphatic stomata' of the subpleural space within the diaphragm [63]. The latter communicates with the mesothelial lining, which can also express lymphatic markers [27]. The lymphatic fate determinant, Prox-1 also plays roles in the development of the liver and the pancreas. In the pancreas, Prox-1 regulates liver development [132] by controlling hepatoblast delamination and migration. Embryos of Prox-1 $1^{-/-}$mice have smaller livers due to reduced numbers of hepatocyte clusters. This phenomenon appears to reflect excess E-cadherin expression that restricts cell movement [133]. Prox-1 is also necessary for adult liver homeostasis as its deletion produces several defects in the liver function.

\section{Gallbladder}

In humans, the gallbladder has three lymphatic networks: muscular, perimuscular and subserosal. The gallbladder and bile ducts share lymphatic networks that adjoin one another, and are known as the sub-mucosal and sub-serous lymphatic plexuses. These networks drain into the hepatic nodes, particularly the cystic node and that of the epiploic foramen. Lymph then proceeds from the celiac node to intestinal lymphatic trunks, the union of the abdominal lymphatic trunks and lastly, to the thoracic duct. Although lymphatics are present in all these 
regions, the lymphatic vessel density (LVD) has been shown to be highest in the perimuscular (subserosal), lower in the muscular, and the lowest in the mucosal layers [134]. The high LVD in the sub-serous layers has been suggested to promote tumor spread and it has been found that patients with tumors that invade this layer have poorer prognosis than patients whose tumor lymphatics are restricted to the superficial layers [134]. The lymphatics of gallbladder appear to connect with lymphatics of the liver, and the pancreas, which may have pathophysiological relevance. Weiner et al., [135] showed that experimental inflammation of the gallbladder led to inflammatory changes in the pancreas, which might be promoted by lymphatic transport.

\section{Pancreas}

Pissas et al. [136] describe two divisions of lymph vessels of the pancreas: a "primary mesodorsal region" of the pancreas composed of the right side retroportal process and a left side lateroportal process. Pancreatic terminal collecting lymphatics in the pancreas are short, merging near the origin of the thoracic duct. The majority of the vessels within the pancreas' lymphatic network are in the interlobular septa of the connective tissue that separates the pancreas into lobes and lobules. Extensions of these interlobular lymphatics can be seen in the lobules but such lymphatics are not abundant [137]. Dye injection studies in the pancreas show that lymph vessels form a widespread interlobular network closely associated with blood vessels. In contrast, no lymphatics appear to enter or arise in the islets of Langerhans [138]. Pancreatic lymph collects from the pancreaticoduodenal, pancreaticosplenic and pyloric nodes entering the celiac nodes, leading to intestinal lymph trunks, union of abdominal lymphatics and finally, to the thoracic duct. It has been reported that chronic pancreatitis obliterates some pancreatic sub-capsular lymphatic 'channels [139], which is interpreted as evidence that interruptions in lymphatic flow might contribute to disease severity. Increased pancreatic duct pressure can be relieved by increased lymphatic flow and protects the pancreas from injury. The blockade or ligation of proximal pancreatic lymphatic efferent vessels provokes severe pancreatitis via release of toxic proteolytic enzymes. Antiproteases can block development of shock mediated by the release of these cytotoxic enzymes into lymph with transfer to the general circulation in pancreatitis. Lymph containing such cytotoxic enzymes is also referred as 'shock' lymph.

Prox-1 is a critical regulator of pancreas 'bud' development [140]. Prox $-1^{-1-}$ mice have disturbed pancreas epithelial organization, reduced pancreas size, but unaffected early endocrine cell development. By embryonic day 13.5, Prox $-1^{-1-}$ mice have reduced numbers of islet precursors, so that by the " $2^{\circ}$ transition" relatively fewer cells are available for later pancreatic maturation; it is unclear how the Prox $1^{-/-}$phenotype relates to cadherin expression. Conditional deletion of Prox-1 causes exocrine cell apoptosis, inflammation and impaired function of the pancreas. Prox-1 is abundantly expressed in adult pancreas [141] linking adipogenesis, insulin action and obesity. In non-obese diabetes, pancreatic LECs lose expression of 5'-nucleotidase and increase CCL21 in an age-dependent fashion, (not seen in controls), driving leukocyte infiltration [89].

\section{Lymphatic GI pathophysiology}

\section{Lymphatics as a hormone conducting network in the GI system?}

Lymphatics have been suggested to act as a parallel conduit for some hormones and autacoids (local acting hormones). Many enzymes are present in lymph (aldolase, alkaline and acid phosphatases, lactate dehydrogenase, diamine oxidase and amylase). Fat-feeding increases $\mathrm{Cu}$-amine oxidase/histaminase secretion into lymph. Pilocarpine also triggers pancreatic release of amylase, lipases and proteases which can appear in lymphatics [91;142]. Insulin has been measured in thoracic duct lymph [143] and insulin transported in 
visceral lymph might bypass the liver to retain the $\sim 50 \%$ insulin destroyed via portal venous flow [91;144]. However, lymphatic insulin appears to reflect filtration from blood, rather than direct release into lymph. O'Morchoe [137] found that normally, pancreatic exocrine or endocrine secretion into the thoracic duct is not physiologically significant, but it can become important in the setting of acute or chronic pancreatitis.

\section{Lymphatic pathophysiology producing GI disease}

Defects in GI lymphatic patterning and structure, lymphatic pump function and GI lymphatic obstruction or remodeling produce several forms of GI pathology and exacerbate GI injury. Lymph flow is affected by a variety of factors, including the state of hydration of the interstitial compartment, external compression forces generated by gut motility (extrinsic) and lymphatic contractile (intrinsic) forces. While gastrointestinal lymphatics normally maintain ISF volume by clearing fluid entering the mucosal and submucosal tissue layers, during pathological inflammation, lymphatic clearance is insufficient to prevent accumulation of excess ISF, generating edema and dilating lymph vessels. Another effect of lymphatic insufficiency can be an accumulation of immune cells in the mucosa and submucosa. Prolonged residence times of cytotoxic cells within the gut wall are thought to contribute to the immune cell-mediated tissue injury accompanying chronic gut inflammation. Further, if the uptake and transfer of gut luminal antigens by mucosal macrophages is an essential step in triggering adaptive immunity, then an impaired transport of immune cells in gut lymphatics may contribute to the dysregulated immune response that initiates chronic gut inflammation.

\section{Protein-losing enteropathies}

Protein-losing enteropathies are characterized by the progressive loss of protein from bowel due to elevated lymphatic pressure, lymphatic congestion and non-ulcerative mucosal disease as well as inflammatory and ulcerative diseases. Primary intestinal lymphangiectasia (PIL, Waldmann's disease) and intestinal lymphatic hypoplasia (ILH). PIL and ILH, two important forms of protein-losing enteropathy, share some clinical features with different root causes. PIL ('Waldmann's disease') [143;143;145] is a childhood bilateral lower limb edema exhibiting protein-losing enteropathy with nausea, abdominal pain, diarrhea/steatorrhea (fatty stools) [146]. The lymphangiectasia (pathologic lymphatic dilation) in PIL (seen in obstructed, distended small intestinal lymphatic lacteals) causes the gut to leak lymph back into the lumen, with malabsorption of protein (proteinlosing enteropathy) and fat. Lymphedema may develop in PIL wherever lymphatics become blocked including sites outside GI system [147]. Levels of serum albumin and $\gamma$-globulin are low in PIL and can result in a hypo-oncotic-driven edema (hence PIL's described as 'Idiopathic Hypoproteinemia'). This large loss of fluid also causes lymphocytes to be lost from the blood circulation, producing lymphopenia. PIL results from improperly formed lymph vessels and is diagnosed by small intestine biopsy, which shows dilated lymphatics. Plasma alpha1-antitrypsin (A1-AT) is shed in PIL and other forms of protein losing enteropathies (PLE) and is used as an index of GI protein loss. As A1-AT is an inhibitor of elastase, A1-AT deficiency may increase susceptibility to neutrophil injury [148] and is correlated with Crohn's' disease etiology [149]. A low fat/ high protein diet for PIL is used to help limit lymphatic dilation and protein loss. Lupus and lymphedema may develop wherever lymphatics become blocked including sites outside the GI system [147]. Lupus and other collagen vascular diseases like Scleroderma, Whipple's disease, various forms of obstructive lymphomas, sclerosing mesenteritis, mesenteric sarcoidosis and mesenteric tuberculosis can also provoke PLE. PIL is associated with increased levels of mucosal VEGFR-3 and LYVE-1, but low levels of VEGF-C and D, suggesting that increased VEGFR-3 anticipates VEGF-C/D production necessary for normal homeostasis. There is a relatively reduced density of VEGFR $-3^{+}$LYVE-1 vessels in the deeper mucosa. Intestinal 
lymphatics in PIL also contain low levels of FoxC2 and SOX18, two important lymphatic patterning genes [150] but normal Prox1.

\section{Intestinal lymphatic hypoplasia}

Intestinal lymphatic hypoplasia a congenital protein-losing enteropathy is usually detected in infancy [151]. Intestinal lymphatic hypoplasia is characterized as a condition with fewer podoplanin $^{+}\left(\mathrm{D} 2-40^{+}\right)$vessels which alters gut tissue function provoking protein losing enteropathy [152]. Stormon et al. [153] have reported that lymphatic hypoplasia in utero 'fetal hydrops ' (prenatal ascites and generalized edema). While lymphangiectasia is characterized by defective, usually distended and obstructed lymphatics, lymphatic hypoplasia histologically presents many fewer lymphatics, and without lymphopenia.

\section{Nonne-Milroy-Meige syndrome}

Nonne-Milroy-Meige syndrome is now recognized as two distinct diseases which are Hereditary Lymphedemas (HL) type I (Nonne-Milroy, Milroy's disease) and hereditary lymphedema type II (Meige's syndrome, ('MS'), also known as familial lymphedema praecox). These are defined by the age of onset. HL type I appears before age 35; HL type II appears after 35y. Nonne-Milroy's disease (NMD) [154], a congenital form of lymphedema, usually appears early in females as a unilateral lower limb edema that may progress to bilateral edema. NMD is an autosomal dominant condition, and the least common heritable form of lymphedema (NMD is $\sim 2 \%$ of inherited lymphedemas). NMD is caused by defects in VEGFR-3 signaling which have been mapped to chromosome 5q, (5q34-q35 region). These VEGFR-3 mutations lead to errors in lymphatic development and lymphatic failure [155]. NMD is often characterized by steatorrhea, (reflecting the failure of intestinal lymphatics to adequately transport chylomicrons) with chylous ascites and lymphopenia due to loss of lymph retention, which is often associated with impaired cell-mediated immunity. NMD is also a protein-losing enteropathy known as intestinal lymphangiectasia with peripheral lymphedema. Additionally, defects in reelin have also been suggested to mediate some forms of primary lymphedema [156]. At present MS appears to be distinct from NMD. According to Rezaie et al., FOXC2 mutations when present reflect lymphadema distichiasis rather than MDS [157].

\section{Lymphedema distichiasis (LD)}

Lymphedema distichiasis is collection of $>30$ autosomal dominant mutations in FOXC2 (chromosome 16q24.3) causing a pubertal lymphedema and double row of eyelashes (distichiasis). LD is characterized by a normal or increased number of hypo-functioning lymphatics with a higher than normal pericyte-smooth muscle investment. Petrova et al., have reported that this phenomenon is due to unchecked amplification of PDGF signaling in lymphatics in FOXC2 haploinsufficient mice reminiscent of defective lymphatic drainage similar to that observed in LD patients $[38 ; 67 ; 158]$. LD also shows lymph node proliferation (in the form of grape clusters) and has a male predominance [159]. Mice haploinsufficient for FOXC2 have lymphedema and lymphatic reflux into the mesenteric lymph nodes, liver and intestine [158]; however a GI phenotype in humans with LD has not been described (LD is not associated with PLE).

Hennekam's syndrome. Hennekam's syndrome (HS) is a congenital autosomal recessive lymphedema described by Dutch physician Raoul Hennekam in 1989 [160]. HS is another form of protein-losing enteropathy characterized by intestinal lymphangiectasia with hypoproteinemia, hypo- $\gamma$-globulinemia and lymphocytopenia. Lymphocyte shedding in HS may also contribute to subtle immune abnormalities. Pleural lymphangiectasia is also present in HS and is accompanied by facial abnormalities (flat face and nasal bridge, widely set eyes often with epicanthal folds, small mouth, dental and ear defects), lymphedema, 
cellulitis and erysipelas (skin infections usu. Strep. spps). The gene responsible for the generalized lymphedema found in HS, (mapped to chromosome 15q) [38] has recently been found, and is currently being investigated (pers. comm. Dr. R.C.M. Hennekam). Conditions producing venous obstruction can also provoke protein-losing enteropathy including right heart failure [161], constrictive pericarditis [162;163], familial cardiomyopathy [164], interatrial septal defect [165]. Lutembacher's syndrome (septal defect with mitral stenosis) [166] and pulmonary stenosis [167]. Constrictive pericarditis provokes lymphatic dilation and increased loss of lymph protein and lymphocytes (lymphopenia). Most recently, Meadows et al., [168] reported that patients with congenital heart disease and protein-losing enteropathy often show evidence of lymphatic obstruction whereas patients undergoing Fontan repair show venous congestion and PLE [169].

\section{Aagenaes's syndrome}

Aagenaes's syndrome (AS, named for Norwegian physician Øystein Aagenaes) is a congenital form of lymphedema with intrahepatic cholestasis (also 'cholestasis lymphedema syndrome'). This lymphedema affects the lower torso [170]. Lymphatic vascular development in peribiliary tracts is deficient and may underlie development of this disease. AS is the most common in Norway, followed by Europe and USA. Fifty percent of all AS cases are in Norway with $\sim 3 \%$ frequency in gene alteration in southern Norway alone. AS has been reported as autosomal recessive and has been mapped to chromosome 15q. Dominant forms of AS have been reported in non-Norwegians but the genetic basis is not yet identified.

\section{Noonan syndrome}

Noonan syndrome (NS) is another congenital condition which also exhibits lymphatic dysplasia. It shows autosomal dominant inheritance and in $\sim 50 \%$ of individuals is caused by a mutation in protein tyrosine phosphatase-N11, (SHP-2) (chromosome 12q24.1). Mutations in KRAS and SOS1 have also been associated with the development of NS [171] but lymphatic pathology is not a major symptom of NS. Some cases of NS will exhibit intestinal lymphangiectasia [172].

\section{Yellow Nail Syndrome}

Yellow-nail syndrome (YNS) is a disorder apparently caused by poor lymphatic drainage due to hypoplastic lymphatic vessels; there is evidence for intestinal lymphangiectasia and PLE in YNS [173]. While YNS has been reported as an autosomal dominant condition (associated with FOXC2), at least some cases may not have a documented underlying genetic basis [174].

\section{GI diseases involving lymphatic dysfunction}

In 1935 Pullinger and Florey described increased lymphangiogenesis as an important consequence of inflammation [175]. Because lymphatics play central roles in normal GI function, lymphangiogenesis is a prominent but often overlooked feature of GI inflammation. Crohn's disease (CD) and ulcerative colitis (UC). Despite divergent causes, Crohn's disease and ulcerative colitis both exhibit evidence of lymphatic disturbances. Van Kruningen and Colombel, (2008) have summarized contributions of lymphangitis and lymphangiectasia to CD etiology [176;177]. While many CD current studies focus on genetics and gut flora, lymphatic sclerosis [120;123] produce segmental lymphocytic and granulomatous lymphangitis even showing enteric and cutaneous fistulae. Using antipodoplanin immunohistochemistry Kaiserling et al., [178] and Geleff et al., [179] have demonstrated significant increased lymphangiogenesis (increases in the abundance of lymphatic capillaries) in CD and UC. In the large intestine, the lymphatic capillaries are 
normally found in the lower third of the mucosa. Significant lymphatic vessel expansion is seen in the muscularis mucosae, the tunica submucosa and the tunica subserosa and was often associated with regions where chronic inflammation had converted to fibrosis. An example of lymphatic expansion in these diseases is shown in Fig. 3. Podoplanin ${ }^{+}$lymphatic expansion is seen in all areas of the colon mucosa in ulcerative colitis (UC) and in the colonic and ileal mucosae of patients with UC and CD, respectively [178;179]. Geleff found similar patterns of lymphatic expansion in CD and UC, and that these disease associated lymphatic changes were still found in end-stage disease. Lymphatic proliferation in the gut mucosa during inflammation may therefore compensate for lymphatic insufficiency due to obstruction, pump failure or obliteration as seen in IBD, where there is an increase and redistribution of lymphatic vessels. In UC, lymphatics that are normally found only under the muscularis mucosa expand deeply into the colon lamina propria and submucosa. The scale of this lymphatic redistribution into the mucosa/submucosa seems to be closely related to severity of the disease and that colon lymphatic expansion into the mucosa during active IBD regresses with disease remission.

Tonelli et al., (2000) have also suggested that a congenital failure of primary lymphatic valves may underlie edema and inflammation in Crohn's disease, and possibly other forms of GI inflammation [180]. Failure of lymphatic pumps produced by several inflammatory mediators intensifies the development of edema and lymphangitis [17]. Wu et al., [18] showed that the rate of lymphatic pumping is decreased in experimental IBD, apparently mediated action of $\mathrm{PGE}_{2}$ and $\mathrm{PGI}_{2}$ [181]. Relief of intestinal lymph congestion reduces this type of edema and protein loss [182]. In Crohn's, proliferated lymphatics have been suggested as a basis for the lymphatogeneous metastasis of malignant cells from the gut.

All forms of IBD show cytokine dysregulation [183] including lymphatic-active cytokines. The release of IL-3 by lamina propria monocytes is decreased in CD and UC, and is reversed by hydrocortisone/5-ASA therapy [183]. Elevated IL-7, an inducer of VEGF-D [184;185] is seen during clinical remission of IBD [186]. TNF- $\alpha$, a central regulator in CD and UC, may dysregulate lymphatic phenotypic markers such as LYVE-1 [47;187]. While TNF- $\alpha$ drives VEGF-C and lymphatic expansion in inflammation [188], antibodies to TNF$\alpha$ relieve inflammation and increase lymphangiogenesis [189]. Lymphatics could promote immune cell egress and help to attenuate immune-cell driven chronic inflammation.

\section{Mesenteric venous thrombosis and IBD}

Hatoum et al. [190] have described mesenteric venous thrombosis (MVT) as an infrequent but clinically severe syndrome that interrupts flow causing intestinal ischemia, often triggering portal hypertension. An association between inflammatory bowel disease (IBD) and MVT was seen in $1.1 \%$ of IBD cases and may contribute to injury through lymphatic derangement. Fibrosis and obstruction of lymphatic vessels produced by tuberculosis, appendicitis/peritonitis, [191] or experimental obstruction of lymphatic vessels [192] can also lead to protein-losing enteropathies which resemble congenital protein-losing syndromes.

\section{Menetrier's disease}

Menetrier's disease (hyperplastic-hypersecretory gastropathy) is a form of gastric hyperplasia characterized by mucosal thickening and mucus production, which is mediated, in part, by defects in lymphatics. Miura et al., [193] correlated epithelial hyperplasia and edema of the lamina propria / submucosa with increased lymphatic density, lymph nodes and lymphangiectasia in this condition. The pediatric form of Menetrier's appears to represent a response to $H$. pylori or cytomegalovirus infection and often resolves spontaneously, while the adult form is chronic and is mediated by TGF- $\alpha$ expression 
[194;195]. Both forms of Menetrier's are protein-losing gastropathies (i.e. albumin is shed from the gastric lining). Similarly lymphangioleiomyomatosis, a smooth muscle hyperproliferation often associated with airway, vascular obstruction from smooth muscle proliferation and chylous effusions, can also induce a protein-losing gastro-enteropathy [196].

\section{Pancreatitis}

Pancreatitis is characterized by forms of blood vascular and lymphatic injury including thrombosis, hemorrhage, edema, inflammation and is often associated with severe hypotension. Pancreatic lymph flow increases in acute pancreatitis [197], with elevation in amylase and lipases in the thoracic duct. Dupont \& Litvine [198], Pissas et al., [136] and O'Morchoe et al. [137] have described pancreatitis as having an important lymphatic component, where lymphatic failure to clear edema fluid leads to accumulation of exocrine secretions and pancreatic injury. Obstruction of the cisterna chyli will also increase pancreatic edema and exacerbate forms of pancreatitis. Pissas et al., state that 'pancreatic edema...is essentially a "lymphatic" edema..' Experimental ligation of proximal pancreatic lymphatic efferents produced fatal necrotic pancreatitis. Penn et al., 2007 [199] describe 'autodigestion', an injury mechanism for formation of highly toxic mediators created in the intestine in response to the liberation of pancreatic proteases, a potentially important phase of shock injury. Insulitis may also influence pancreatic function. Following development of insulitis in non-obese mice, Qu et al., [200] observed that lymphatic endothelium in the pancreas loses 5'-nucleotidase and expresses CCL21, which may increase binding and migration of lymphocytes and dendritic cells, an effect correlated with blood glucose levels. Amylase and lipase are also elevated in thoracic duct lymph in acute pancreatitis [201] as well as alkaline phosphatase that is shed into lymph from brush border [9]. Montravers et al., [202] have described that diversion of cytokines (TNF- $\alpha$, IL-1 $\beta$, IL-6), proteases (amylase, trypsin) and lipase released by the inflamed pancreas (through thoracic duct cannulation) protects the lung against induction of respiratory distress injury.

\section{Shock, Lymph and the GI system}

GI lymphatics play central roles in pathological responses to hemorrhagic shock, trauma and intestinal ischemia [203] by conveying an array of toxic mediators generated within the GI system back to the blood circulation, triggering a systemic often 'distant' organ injury with lethal implications. Several GI organs, especially the post-ischemic small intestine, generate toxic lymph which mobilizes endothelial P-selectin, injures microvessels and disturbs cardiac performance [204-206]. Mesentery-derived 'shock' lymph produced by non-lethal hemorrhage (but not portal venous plasma) activates neutrophils [207], increases vascular permeability and can induce cell death. Mediators present in 'shock' lymph which cause injury and cell stress include complement [208] and cytokines (e.g., TNF- $\alpha$, IL-6, IL-1 $\beta$ and LPS) [209;210]. In particular, IL-1 $\beta$ (produced in the gut and carried in lymph) mediates remote pulmonary injury after intestinal ischemia [211]. Although relatively distant from the mesentery, the lung and heart are often downstream targets of remote organ injury due to effects of 'shock' lymph [203;212] delivered by the thoracic duct.

\section{Whipple's disease (WD)}

WD is a rare gastrointestinal disease caused by the Tropheryma whipplei bacterium. WD is another malabsorptive condition characterized by weight loss, chronic diarrhea, weakness, fever, lymphadenopathy, arthralgia (joint pain), steatorrhea, polyarthropathy, macrophage infiltration of the lamina propria and lymphopenia [213]. IL-12, IFN- $\gamma$ and IFN- $\gamma$ dependent $\mathrm{IgG} 2$ and TGF- $\beta$ are reduced in WD. WD shows evidence of lymphatic blockade, enlarged and often fatty lymph nodes and distended lymphatic vessels [214]. Clinically, Whipple cells have been shown to circulate in thoracic duct lymph [215] and lymphatics are the 
primary route for the transport of WD microorganisms and abnormal immune cells from the GI tract to the circulation. Similarly, lymph in tuberculous enteritis, has also been shown to transport tubercle bacilli [216].

\section{Cirrhosis}

Cirrhosis (or portal venous obstruction) will produce portal hypertension and a large increase in lymph flow. In cirrhosis, the lymph flow rate can be 6-10-fold higher than normal (from 0.8 up to $8 \mathrm{ml} / \mathrm{min}$ ) [217] dilating the thoracic duct to 2-4-fold from the normal size. There is frequently an increased lymphatic density in cirrhosis [28], which may represent a physiological compensation. The hepatic lymphatic overload in cirrhosis reflects sinusoidal hypertension leading to increased formation of lymph. Although shedding of lymph at the liver surface is seen experimentally, it is not universally observed in human disease [218]. During portal hypertension or cirrhosis, the increased flow of fluid and solutes from the gut lumen to lymph allows several classes of bioactive mediators to enter the lymph, bypassing the liver where they might normally be degraded, sometimes with morbid consequences. Whenever hepatic venous outflow is impaired provoking portal hypertension (as in cirrhosis, end-stage liver disease), increased hepatic lymph flow dilates the space of Disse. This phenomenon is most prominent in acute 'Budd-Chiari' syndrome (blocked hepatic venous outflow resulting from thrombosis, or its fibrotic sequelae at different regions from small hepatic veins to the inferior vena cava) or right heart failure. Because hepatic sinusoidal pressure is low $(3-5 \mathrm{~mm} / \mathrm{Hg})$ and sinusoidal endothelial permeability is high, even small restriction to hepatic venous outflow will increase lymph flow in human and experimental cirrhosis. The increased hepatic lymph flow combined with elevated intestinal lymph flow raises pressure in the cisterna chyli, further restricting intestinal lymph flow to produce intestinal edema [219;220] linking hepatic lymph homeostasis with gut inflammation.

\section{Ascites}

In normal physiology, peritoneal fluid formation is minimal, and diaphragmatic lymphatics efficiently drain the peritoneal cavity. Blood cells and even India ink particulates can enter lymphatics from the diaphragm which communicates with peritoneal and pleural mesothelial lining cells (structurally and ontogenetically continuous with lymphatics) [63;221].

Obstruction or hypertension in the liver or intestine, or blockage of peritoneal drainage increases ascitic fluid derived from these compartments. Defects in lymphatic development and structure can also provoke 'chylous' ascites[222].

\section{Sjogren's disease (SD)}

Garcia-Carrasco et al., [223] describe benign and malignant lymphoproliferation in SD. SD sufferers carry an increased lifetime risk for developing lymphomas [224], but links between lymphangiogenesis and lymphoma in SD are not yet well established.

\section{GI cancer and lymphatics}

Sentinel lymph nodes and lymphatics transmit cancer cells from primary to distant sites and are commonly used for prognosis and staging of disease [225]. Obstruction of lymphatics and lymph nodes by tumors promotes lymph retention, reflux and hematogenous metastasis, 'jumping' and peritoneal metastasis via lymphatic-venous shunting from the lymphatic system [226]. Yonemura et al., [227] showed that the density and caliber of VEGFR-3+ lymphatic vessels are significantly higher in VEGF-C expressing tumors compared with tumors having low expression of VEGF-C, further supporting VEGFR-3 ${ }^{+} /$VEGF-C signaling in tumor lymphatic recruitment and metastasis. Studies with colorectal carcinoma showed tumor elevated D2 $-40^{+}$lymphatic vessel density, which predicts lymphatic tumor 
invasion with better sensitivity (48/90) than PECAM-1/CD31 (37/90) or (H\&E) (31/90). Increased D2-40+ lymphatic density is correlated with lymphatic invasion and lymph node metastases $(\mathrm{p}<0.05)$ and is related to the depth of tumor invasion, positive vascular pedicle lymph nodes and liver metastases $(\mathrm{p}<0.05)$ [228]. Pancreatic cancer also shows increased VEGFR-3 and VEGF-C expression [141]. Prox 1 expression in the pancreas is lost during malignant transformation. Although Prox1 suppresses cadherins, which are antagonists of cell transformation, diminished Prox 1 may contribute to loss of a differentiated phenotype and progression to carcinoma with poorer survival. Jin et al. [229] suggested that the lymphatic abundance in the superior mesenteric artery neural plexus may play a role in the recurrence of pancreatic cancer, which could be activated by the abundance of lymphangiogenic factors.

\section{Intestinal transplantation and lymphatics}

Obstruction or obliteration of lymphatics produces an intense GI injury [123]. Intestinal transplants underscore the importance of lymphatic maintenance. Duxbury et al., [230] have shown that in intestine transplant models, lymphatics and blood vessels regenerate independently of one another. Kellersman et al., [231] showed that reconstructing intestinal lymphatics significantly improves success in small bowel transplants. Liver lymphostasis (seen as hypodense areas on computerized tomography are also seen after severing lymphatics in liver transplants. This abnormality often resolves by 6 months because lymphatic collaterals gradually regenerate without reconstruction [232].

\section{Transgenic and mutant models with abnormal thoracic duct/intestinal lymphatic system patterning / chylous ascites}

While defects in VEGFR-3, FoxC2 and SOX18 genes are known to contribute to errors in lymphatic development and produce different forms of lymphedema, their dysfunction explains only a small fraction of $1^{\circ}$ lymphedema cases. Ferrell et al., [233] have also found single gene mutations in families with lymphedema within elastin microfibril interfacer (EMILIN1), lymphocyte cytosolic protein 2 (LCP2), fatty acid binding protein 4 (FABP4), protein tyrosine kinase SYK (SYK), neuropilin-2 (NRP2), SpSRY-box 17 (SOX17), VCAM-1, ROR orphan receptor C, and VEGF-B. Among these proteins, FABP4, NRP2, SOX17 and VCAM-1 were most closely linked and may represent a secondary group of lymphedema mutations. Interestingly, the adhesion molecule VCAM-1 appears to be a downstream target of SOX-18 [234] but how it is related to lymphedema is not yet understood. Emilin 1, is an $\alpha 4 \beta 1$ integrin ligand and a component of lymphatic anchoring filaments, also expressed by large vessels (arteries) which may regulate immune cell traffic [235]. Emilin 1 appears to help maintain lymphatic vascular integrity since Emilin ${ }^{-1-}$ mice exhibit lymphedema, lymphatic hyperplasia and enlargement, possibly due to the absence of Emilin from anchoring filaments [134;236]. Several other transgenic mouse models with defects in lymphatic signaling or development exhibit GI defects further underscoring the importance of lymphatics in GI homeostasis. The Chy-3 mouse [237] is hemizygous for VEGF-C and exhibits chylous ascites, with edema in the limbs, skin and genitals, but no overt GI disturbances. Ang-2 deficient mice $[65 ; 66 ; 238]$ fail to develop lymphatics in ear skin and mesentery, do not exhibit a collecting vessel phenotype, and are considered to be a model of intestinal lymphangiodysplasia. In humans, FoxC2 mutations produce lymphedema-distichiasis [239;240] and FoxC2 haplo-insufficient mice have defects in lymphatic patterning, valve defects and lymph reflux [158], the homozygous FOXC2 ${ }^{-/-}$ phenotype is lethal. 


\section{Lymphatic defects in adult-onset obesity?}

Mice deficient for the lymphatic-fate determining transcription factor Prox-1 (Prox- $1^{+/-}$) exhibit lymphedema with severe defects in the intestinal and mesenteric lymphatics [54]. This phenotype has a high level of perinatal mortality, and interestingly, provokes adult onset obesity. Prox $-1^{+/-}$mice have normal insulin and leptin levels as pups, but progress to elevated insulin resistance and leptin as adults [141] and suggest a remarkable 'paradigm shift' in our understanding of the mechanisms underlying obesity. Further support for this concept is seen in studies showing that FOXC2 controls the types and distribution of fat depots in regulating insulin resistance [38;241;242]. Pro-lymphangiogenic FoxC2 and other forkhead transcription factors may therefore have major effects on metabolism. Conversely, the onset of obesity may also trigger lymphedema [243], suggesting that cyclical patterns of lymphatic injury and failure may exacerbate stresses associated with obesity. Pathologically increased adipose tissue is often a prominent feature of both forms $\left(1^{\circ}\right.$ and $\left.2^{\circ}\right)$ lymphedema, and liposuction has been used as treatment to reduce excess tissue volume [244]. Obesity is also associated with an increase in both hemangiogenic and lymphangiogenic regulatory factors (VEGF-C, VEGF-D, sVEGF-R2, angiopoietin-2, angiogenin as well as endostatin) [245]. Alterations in the levels of these vasoregulatory factors could modulate adipose tissue vascularity. However, the relationship between these obesity-induced vascular regulators and lymphatic integrity is still unclear. Serum VEGF-D shows sexual dimorphism: higher VEGF-D is found in lean females than lean males. Obese females have higher VEGF-C and Ang-2 levels than obese males. These factors may be controlled by metabolic status and could intensify angiogenesis and inflammation.

\section{Summary}

Normal lymphatic structure and function supports the absorptive and immune functions of the GI tract. Dilated or congested lymphatics fail to transport ISF and exacerbate GI disease by increasing the GI tracts' vulnerability to edema, poor perfusion, inflammatory injury and dysregulation of the immune system. Similarly, congenital defects in lymphatic patterning or development often produce similar forms of GI pathology. Changes in the flow and composition of lymph may also modulate GI disease and distant organ injury [246]. Despite a current wealth of tools for exploring roles of lymphatics in GI under normal and pathophysiological conditions, we still lack methods to directly image lymphatics. Effort is still needed to focus energy and attention on biology and pathobiology of the GI lymphatics to discover new markers and design new treatments for the disorders of GI tract.

\section{Acknowledgments}

The authors would like to acknowledge Ms. Shannon Wells for superior technical and editorial assistance with this manuscript and Dr. Traci Testerman for valuable suggestions.

\section{Reference List}

1. Potter, P. On Glands. Vol. Vol VIII. Cambridge: Harvard University Press; 1995. Hippocrates; p. 108-125.

2. Crivellato E, Travan L, Ribatti D. The Hippocratic treatise 'On glands': the first document on lymphoid tissue and lymph nodes. Leukemia 2007;21:591-592. [PubMed: 17375122]

3. Chikly B. Who discovered the lymphatic system. Lymphology 1997;30:186-193. [PubMed: 9476250]

4. Granger DN. Intestinal microcirculation and transmucosal fluid transport. Am J Physiol 1981;240:G343-G349. [PubMed: 7015880]

5. Granger DN, Barrowman JA. Microcirculation of the alimentary tract I. Physiology of transcapillary fluid and solute exchange. Gastroenterology 1983;84:846-868. [PubMed: 6337911] 
6. Granger DN, Barrowman JA. Microcirculation of the alimentary tract. II. Pathophysiology of edema. Gastroenterology 1983;84:1035-1049. [PubMed: 6339310]

7. Olszewski, W., et al. Lymph Stasis: Pathophysiology, Diagnosis, and Treatment. Boca Raton, FL: CRC Press; 1991. p. 1-619.

8. Fujimoto K, Price VH, Granger DN, Specian R, Bergstedt S, Tso P. Effect of ischemia-reperfusion on lipid digestion and absorption in rat intestine. Am J Physiol 1991;260:G595-G602. [PubMed: 2018134]

9. Fanous MY, Phillips AJ, Windsor JA. Mesenteric lymph: the bridge to future management of critical illness. JOP 2007;8:374-399. [PubMed: 17625290]

10. Zawieja DC, Davis KL. Inhibition of the active lymph pump in rat mesenteric lymphatics by hydrogen peroxide. Lymphology 1993;26:135-142. [PubMed: 8258987]

11. Zawieja DC. Lymphatic microcirculation. Microcirculation 1996;3:241-243. [PubMed: 8839448]

12. Hangai-Hoger N, Cabrales P, Briceno JC, Tsai AG, Intaglietta M. Microlymphatic and tissue oxygen tension in the rat mesentery. Am J Physiol Heart Circ Physiol 2004;286:H878-H883. [PubMed: 14630627]

13. Hangai-Hoger N, Tsai AG, Cabrales P, Intaglietta M. Terminal lymphatics: the potential "lethal corner" in the distribution of tissue pO2. Lymphat Res Biol 2007;5:159-168. [PubMed: 18035934]

14. Ohhashi T, Mizuno R, Ikomi F, Kawai Y. Current topics of physiology and pharmacology in the lymphatic system. Pharmacol Ther 2005;105:165-188. [PubMed: 15670625]

15. Muthuchamy M, Zawieja D. Molecular regulation of lymphatic contractility. Ann N Y Acad Sci 2008;1131:89-99. [PubMed: 18519962]

16. Muthuchamy M, Gashev A, Boswell N, Dawson N, Zawieja D. Molecular and functional analyses of the contractile apparatus in lymphatic muscle. FASEB J 2003;17:920-922. [PubMed: 12670880]

17. von der Weid PY, Zawieja DC. Lymphatic smooth muscle: the motor unit of lymph drainage. Int J Biochem Cell Biol 2004;36:1147-1153. [PubMed: 15109561]

18. Wu TF, MacNaughton WK, von der Weid PY. Lymphatic vessel contractile activity and intestinal inflammation. Mem Inst Oswaldo Cruz 2005;100 Suppl 1:107-110. [PubMed: 15962107]

19. Zawieja D. Lymphatic biology and the microcirculation: past, present and future. Microcirculation 2005;12:141-150. [PubMed: 15804980]

20. Zawieja DC, Davis KL, Schuster R, Hinds WM, Granger HJ. Distribution, propagation, and coordination of contractile activity in lymphatics. Am J Physiol 1993;264:H1283-H1291. [PubMed: 8476104]

21. Zawieja DC. Contractile physiology of lymphatics. Lymphat Res Biol 2009;7:87-96. [PubMed: 19534632]

22. Podgrabinska S, Braun P, Velasco P, Kloos B, Pepper MS, Skobe M. Molecular characterization of lymphatic endothelial cells. Proc Natl Acad Sci U S A 2002;99:16069-16074. [PubMed: 12446836]

23. Oliver G, Sosa-Pineda B, Geisendorf S, Spana EP, Doe CQ, Gruss P. Prox 1, a prospero-related homeobox gene expressed during mouse development. Mech Dev 1993;44:3-16. [PubMed: 7908825]

24. Nibbs RJ, Kriehuber E, Ponath PD, Parent D, Qin S, Campbell JD, Henderson A, Kerjaschki D, Maurer D, Graham GJ, Rot A. The beta-chemokine receptor D6 is expressed by lymphatic endothelium and a subset of vascular tumors. Am J Pathol 2001;158:867-877. [PubMed: 11238036]

25. Samama B, Boehm N. Reelin immunoreactivity in lymphatics and liver during development and adult life. Anat Rec A Discov Mol Cell Evol Biol 2005;285:595-599. [PubMed: 15912522]

26. Petrova TV, Makinen T, Makela TP, Saarela J, Virtanen I, Ferrell RE, Finegold DN, Kerjaschki D, Yla-Herttuala S, Alitalo K. Lymphatic endothelial reprogramming of vascular endothelial cells by the Prox-1 homeobox transcription factor. EMBO J 2002;21:4593-4599. [PubMed: 12198161]

27. Ando T, Langley RR, Wang Y, Jordan PA, Minagar A, Alexander JS, Jennings MH. Inflammatory cytokines induce MAdCAM-1 in murine hepatic endothelial cells and mediate alpha-4 beta-7 integrin dependent lymphocyte endothelial adhesion in vitro. BMC Physiol 2007;7:10. [PubMed: 17868448] 
28. Mouta CC, Nasser SM, di TE, Padera TP, Boucher Y, Tomarev SI, Jain RK. LYVE-1 is not restricted to the lymph vessels: expression in normal liver blood sinusoids and down-regulation in human liver cancer and cirrhosis. Cancer Res 2001;61:8079-8084. [PubMed: 11719431]

29. Wrobel T, Dziegiel P, Mazur G, Zabel M, Kuliczkowski K, Szuba A. LYVE-1 expression on high endothelial venules (HEVs) of lymph nodes. Lymphology 2005;38:107-110. [PubMed: 16353487]

30. Niemela H, Elima K, Henttinen T, Irjala H, Salmi M, Jalkanen S. Molecular identification of PALE, a widely used endothelial-cell marker. Blood 2005;106:3405-3409. [PubMed: 16099878]

31. Groger M, Niederleithner H, Kerjaschki D, Petzelbauer P. A previously unknown dermal blood vessel phenotype in skin inflammation. J Invest Dermatol 2007;127:2893-2900. [PubMed: 17882274]

32. Hong YK, Detmar M. Prox1, master regulator of the lymphatic vasculature phenotype. Cell Tissue Res 2003;314:85-92. [PubMed: 12883994]

33. Groger M, Loewe R, Holnthoner W, Embacher R, Pillinger M, Herron GS, Wolff K, Petzelbauer P. IL-3 induces expression of lymphatic markers Prox-1 and podoplanin in human endothelial cells. J Immunol 2004;173:7161-7169. [PubMed: 15585837]

34. Francois M, Caprini A, Hosking B, Orsenigo F, Wilhelm D, Browne C, Paavonen K, Karnezis T, Shayan R, Downes M, Davidson T, Tutt D, Cheah KS, Stacker SA, Muscat GE, Achen MG, Dejana E, Koopman P. Sox 18 induces development of the lymphatic vasculature in mice. Nature 2008;456:643-647. [PubMed: 18931657]

35. Irrthum A, Devriendt K, Chitayat D, Matthijs G, Glade C, Steijlen PM, Fryns JP, Van Steensel MA, Vikkula M. Mutations in the transcription factor gene SOX18 underlie recessive and dominant forms of hypotrichosis-lymphedema-telangiectasia. Am J Hum Genet 2003;72:14701478. [PubMed: 12740761]

36. Wigle JT, Harvey N, Detmar M, Lagutina I, Grosveld G, Gunn MD, Jackson DG, Oliver G. An essential role for Prox 1 in the induction of the lymphatic endothelial cell phenotype. EMBO J 2002;21:1505-1513. [PubMed: 11927535]

37. Mishima K, Watabe T, Saito A, Yoshimatsu Y, Imaizumi N, Masui S, Hirashima M, Morisada T, Oike Y, Araie M, Niwa H, Kubo H, Suda T, Miyazono K. Prox1 induces lymphatic endothelial differentiation via integrin alpha9 and other signaling cascades. Mol Biol Cell 2007;18:14211429. [PubMed: 17287396]

38. Ferrell RE, Finegold DN. Research perspectives in inherited lymphatic disease: an update. Ann N Y Acad Sci 2008;1131:134-139. [PubMed: 18519966]

39. Dunworth WP, Fritz-Six KL, Caron KM. Adrenomedullin stabilizes the lymphatic endothelial barrier in vitro and in vivo. Peptides 2008;29:2243-2249. [PubMed: 18929609]

40. Blei F. Literature watch. Adrenomedullin signaling is necessary for murine lymphatic vascular development. Lymphat Res Biol 2008;6:45-59. [PubMed: 18361770]

41. Jin D, Harada K, Ohnishi S, Yamahara K, Kangawa K, Nagaya N. Adrenomedullin induces lymphangiogenesis and ameliorates secondary lymphoedema. Cardiovasc Res 2008;80:339-345. [PubMed: 18708640]

42. Schmid-Schonbein GW. The second valve system in lymphatics. Lymphat Res Biol 2003;1:25-29. [PubMed: 15624318]

43. Fritz-Six KL, Dunworth WP, Li M, Caron KM. Adrenomedullin signaling is necessary for murine lymphatic vascular development. J Clin Invest 2008;118:40-50. [PubMed: 18097475]

44. Saban MR, Memet S, Jackson DG, Ash J, Roig AA, Israel A, Saban R. Visualization of lymphatic vessels through NF-kappaB activity. Blood 2004;104:3228-3230. [PubMed: 15271802]

45. Kalogeris TJ, Kevil CG, Laroux FS, Coe LL, Phifer TJ, Alexander JS. Differential monocyte adhesion and adhesion molecule expression in venous and arterial endothelial cells. Am J Physiol 1999;276:L9-L19. [PubMed: 9887050]

46. Karkkainen MJ, Ferrell RE, Lawrence EC, Kimak MA, Levinson KL, McTigue MA, Alitalo K, Finegold DN. Missense mutations interfere with VEGFR-3 signalling in primary lymphoedema. Nat Genet 2000;25:153-159. [PubMed: 10835628]

47. Ji RC. Lymphatic endothelial cells, inflammatory lymphangiogenesis, and prospective players. Curr Med Chem 2007;14:2359-2368. [PubMed: 17896984] 
48. Abtahian F, Guerriero A, Sebzda E, Lu MM, Zhou R, Mocsai A, Myers EE, Huang B, Jackson DG, Ferrari VA, Tybulewicz V, Lowell CA, Lepore JJ, Koretzky GA, Kahn ML. Regulation of blood and lymphatic vascular separation by signaling proteins SLP-76 and Syk. Science 2003;299:247-251. [PubMed: 12522250]

49. Sebzda E, Hibbard C, Sweeney S, Abtahian F, Bezman N, Clemens G, Maltzman JS, Cheng L, Liu F, Turner M, Tybulewicz V, Koretzky GA, Kahn ML. Syk and Slp-76 mutant mice reveal a cellautonomous hematopoietic cell contribution to vascular development. Dev Cell 2006;11:349-361. [PubMed: 16950126]

50. Taniguchi K, Kohno R, Ayada T, Kato R, Ichiyama K, Morisada T, Oike Y, Yonemitsu Y, Maehara Y, Yoshimura A. Spreds are essential for embryonic lymphangiogenesis by regulating vascular endothelial growth factor receptor 3 signaling. Mol Cell Biol 2007;27:4541-4550. [PubMed: 17438136]

51. Backhed F, Crawford PA, O'Donnell D, Gordon JI. Postnatal lymphatic partitioning from the blood vasculature in the small intestine requires fasting-induced adipose factor. Proc Natl Acad Sci U S A 2007;104:606-611. [PubMed: 17202268]

52. Wang Y, Adams RH. Control of angiogenesis and lymphangiogenesis by ephrin-B2. Developmental Biology 2007;435:445.

53. Delzenne NM, Cani PD. Gut microflora is a key player in host energy homeostasis. Med Sci (Paris) 2008;24:505-510. [PubMed: 18466728]

54. Harvey NL, Srinivasan RS, Dillard ME, Johnson NC, Witte MH, Boyd K, Sleeman MW, Oliver G. Lymphatic vascular defects promoted by Prox 1 haploinsufficiency cause adult-onset obesity. Nat Genet 2005;37:1072-1081. [PubMed: 16170315]

55. Fu J, Gerhardt H, McDaniel JM, Xia B, Liu X, Ivanciu L, Ny A, Hermans K, Silasi-Mansat R, McGee S, Nye E, Ju T, Ramirez MI, Carmeliet P, Cummings RD, Lupu F, Xia L. Endothelial cell O-glycan deficiency causes blood/lymphatic misconnections and consequent fatty liver disease in mice. J Clin Invest 2008;118:3725-3737. [PubMed: 18924607]

56. Ichise H, Ichise T, Ohtani O, Yoshida N. Phospholipase Cgamma2 is necessary for separation of blood and lymphatic vasculature in mice. Development 2009;136:191-195. [PubMed: 19056831]

57. Shawber CJ, Kitajewski J. Arterial regulators taken up by lymphatics. Lymphat Res Biol 2008;6:139-143. [PubMed: 19093785]

58. Raub, TJ.; Douglas, SL.; Melchior, GW.; Charman, WN.; Morozowich, W. Methodologies for Assessing Intestinal Lymphatic Transport. In: Charman, WN.; Stella, VJ., editors. Lymphatic Transport of Drugs. CRC Press; 1992. p. 63-113.

59. Baluk P, Fuxe J, Hashizume H, Romano T, Lashnits E, Butz S, Vestweber D, Corada M, Molendini C, Dejana E, McDonald DM. Functionally specialized junctions between endothelial cells of lymphatic vessels. J Exp Med 2007;204:2349-2362. [PubMed: 17846148]

60. Gerli R, Ibba L, Fruschelli C. A fibrillar elastic apparatus around human lymph capillaries. Anat Embryol (Berl) 1990;181:281-286. [PubMed: 2337247]

61. Leak LV, Burke JF. Fine structure of the lymphatic capillary and the adjoining connective tissue area. Am J Anat 1966;118:785-809. [PubMed: 5956107]

62. Pepper MS, Skobe M. Lymphatic endothelium: morphological, molecular and functional properties. J Cell Biol 2003;163:209-213. [PubMed: 14581448]

63. Ohtani O, Ohtani Y, Li RX. Phylogeny and ontogeny of the lymphatic stomata connecting the pleural and peritoneal cavities with the lymphatic system--a review. Ital J Anat Embryol 2001;106:251-259. [PubMed: 11729963]

64. Sell S, Max E. Immunology, Immunopathology and Immunity. American Society for Microbiology 2001:774.

65. Gale NW, Thurston G, Hackett SF, Renard R, Wang Q, McClain J, Martin C, Witte C, Witte MH, Jackson D, Suri C, Campochiaro PA, Wiegand SJ, Yancopoulos GD. Angiopoietin-2 is required for postnatal angiogenesis and lymphatic patterning, and only the latter role is rescued by Angiopoietin-1. Dev Cell 2002;3:411-423. [PubMed: 12361603]

66. Dellinger M, Hunter R, Bernas M, Gale N, Yancopoulos G, Erickson R, Witte M. Defective remodeling and maturation of the lymphatic vasculature in Angiopoietin-2 deficient mice. Dev Biol 2008;319:309-320. [PubMed: 18514180] 
67. Petrova TV, Karpanen T, Norrmen C, Mellor R, Tamakoshi T, Finegold D, Ferrell R, Kerjaschki D, Mortimer P, Yla-Herttuala S, Miura N, Alitalo K. Defective valves and abnormal mural cell recruitment underlie lymphatic vascular failure in lymphedema distichiasis. Nat Med 2004;10:974-981. [PubMed: 15322537]

68. Yuan L, Moyon D, Pardanaud L, Breant C, Karkkainen MJ, Alitalo K, Eichmann A. Abnormal lymphatic vessel development in neuropilin 2 mutant mice. Development 2002;129:4797-4806. [PubMed: 12361971]

69. Kume T. Foxc2 transcription factor: a newly described regulator of angiogenesis. Trends Cardiovasc Med 2008;18:224-228. [PubMed: 19185813]

70. Ganta VC, Cromer WE, Mills GL, Traylor J, Jennings MH, Daley S, Clark B, Mathis JM, Bernas M, Jordan PA, Witte MH, Alexander JS. Angiopoietin-2 in experimental colitis. Inflammatory Bowel Disease. 2009 (In Press).

71. He Y, Rajantie I, Ilmonen M, Makinen T, Karkkainen MJ, Haiko P, Salven P, Alitalo K. Preexisting lymphatic endothelium but not endothelial progenitor cells are essential for tumor lymphangiogenesis and lymphatic metastasis. Cancer Res 2004;64:3737-3740. [PubMed: 15172976]

72. Kerjaschki D, Huttary N, Raab I, Regele H, Bojarski-Nagy K, Bartel G, Krober SM, Greinix H, Rosenmaier A, Karlhofer F, Wick N, Mazal PR. Lymphatic endothelial progenitor cells contribute to de novo lymphangiogenesis in human renal transplants. Nat Med 2006;12:230-234. [PubMed: 16415878]

73. Salven P, Mustjoki S, Alitalo R, Alitalo K, Rafii S. VEGFR-3 and CD133 identify a population of CD34+ lymphatic/vascular endothelial precursor cells. Blood 2003;101:168-172. [PubMed: 12393704]

74. Boardman KC, Swartz MA. Interstitial flow as a guide for lymphangiogenesis. Circ Res 2003;92:801-808. [PubMed: 12623882]

75. Swartz MA, Boardman KC Jr. The role of interstitial stress in lymphatic function and lymphangiogenesis. Ann N Y Acad Sci 2002;979:197-210. [PubMed: 12543729]

76. Goldman J, Conley KA, Raehl A, Bondy DM, Pytowski B, Swartz MA, Rutkowski JM, Jaroch DB, Ongstad EL. Regulation of lymphatic capillary regeneration by interstitial flow in skin. Am J Physiol Heart Circ Physiol 2007;292:H2176-H2183. [PubMed: 17189348]

77. Rutkowski JM, Moya M, Johannes J, Goldman J, Swartz MA. Secondary lymphedema in the mouse tail: Lymphatic hyperplasia, VEGF-C upregulation, and the protective role of MMP-9. Microvasc Res 2006;72:161-171. [PubMed: 16876204]

78. Franchi A, Massi D, Santucci M, Masini E, Degl'Innocenti DR, Magnelli L, Fanti E, Naldini A, Ardinghi C, Carraro F, Gallo O. Inducible nitric oxide synthase activity correlates with lymphangiogenesis and vascular endothelial growth factor- $\mathrm{C}$ expression in head and neck squamous cell carcinoma. J Pathol 2006;208:439-445. [PubMed: 16278821]

79. Nakamura Y, Yasuoka H, Zuo H, Takamura Y, Miyauchi A, Nakamura M, Kakudo K. Nitric oxide in papillary thyroid carcinoma: induction of vascular endothelial growth factor D and correlation with lymph node metastasis. J Clin Endocrinol Metab 2006;91:1582-1585. [PubMed: 16418215]

80. Sawa Y, Yamaoka Y, Ebata N, Ashikaga Y, Kim T, Suzuki M, Yoshida S. Immunohistochemical study on leukocyte adhesion molecules expressed on lymphatic endothelium. Microvasc Res 1999;57:292-297. [PubMed: 10329255]

81. Sawa Y, Sugimoto Y, Ueki T, Ishikawa H, Sato A, Nagato T, Yoshida S. Effects of TNF-alpha on leukocyte adhesion molecule expressions in cultured human lymphatic endothelium. J Histochem Cytochem 2007;55:721-733. [PubMed: 17371935]

82. Sawa Y, Tsuruga E. The expression of E-selectin and chemokines in the cultured human lymphatic endothelium with lipopolysaccharides. J Anat 2008;212:654-663. [PubMed: 18410313]

83. Sawa Y, Tsuruga E, Iwasawa K, Ishikawa H, Yoshida S. Leukocyte adhesion molecule and chemokine production through lipoteichoic acid recognition by toll-like receptor 2 in cultured human lymphatic endothelium. Cell Tissue Res 2008;333:237-252. [PubMed: 18523807]

84. Sawa Y, Ueki T, Hata M, Iwasawa K, Tsuruga E, Kojima H, Ishikawa H, Yoshida S. LPS-induced IL-6, IL-8, VCAM-1, and ICAM-1 expression in human lymphatic endothelium. J Histochem Cytochem 2008;56:97-109. [PubMed: 17938282] 
85. Oka M, Iwata C, Suzuki HI, Kiyono K, Morishita Y, Watabe T, Komuro A, Kano MR, Miyazono $\mathrm{K}$. Inhibition of endogenous TGF-beta signaling enhances lymphangiogenesis. Blood 2008;111:4571-4579. [PubMed: 18310502]

86. Clavin NW, Avraham T, Fernandez J, Daluvoy SV, Soares MA, Chaudhry A, Mehrara BJ. TGFbeta1 is a negative regulator of lymphatic regeneration during wound repair. Am J Physiol Heart Circ Physiol 2008;295:H2113-H2127. [PubMed: 18849330]

87. Issa A, Le TX, Shoushtari AN, Shields JD, Swartz MA. Vascular endothelial growth factor-C and C-C chemokine receptor 7 in tumor cell-lymphatic cross-talk promote invasive phenotype. Cancer Res 2009;69:349-357. [PubMed: 19118020]

88. Kawashima D, Oshitani N, Jinno Y, Watanabe K, Nakamura S, Higuchi K, Arakawa T. Augmented expression of secondary lymphoid tissue chemokine and EBI1 ligand chemokine in Crohn's disease. J Clin Pathol 2005;58:1057-1063. [PubMed: 16189151]

89. Qu P, Ji RC, Kato S. Expression of CCL21 and 5'-Nase on pancreatic lymphatics in nonobese diabetic mice. Pancreas 2005;31:148-155. [PubMed: 16025002]

90. Kriehuber E, Breiteneder-Geleff S, Groeger M, Soleiman A, Schoppmann SF, Stingl G, Kerjaschki $\mathrm{D}$, Maurer D. Isolation and characterization of dermal lymphatic and blood endothelial cells reveal stable and functionally specialized cell lineages. J Exp Med 2001;194:797-808. [PubMed: 11560995]

91. Barrowman JA. Physiology of the gastro-intestinal lymphatic system. Monogr Physiol Soc 1978:ix-312.

92. Leigh OC. Lymph formation during glandular activity. Am J Physiol 1935;112:657-661.

93. Hata M, Ueki T, Sato A, Kojima H, Sawa Y. Expression of podoplanin in the mouse salivary glands. Arch Oral Biol 2008;53:835-841. [PubMed: 18339356]

94. Pammer J, Weninger W, Mildner M, Burian M, Wojta J, Tschachler E. Vascular endothelial growth factor is constitutively expressed in normal human salivary glands and is secreted in the saliva of healthy individuals. J Pathol 1998;186:186-191. [PubMed: 9924435]

95. Taichman NS, Cruchley AT, Fletcher LM, Hagi-Pavli EP, Paleolog EM, Abrams WR, Booth V, Edwards RM, Malamud D. Vascular endothelial growth factor in normal human salivary glands and saliva: a possible role in the maintenance of mucosal homeostasis. Lab Invest 1998;78:869875. [PubMed: 9690564]

96. Brozovic S, Vucicevic-Boras V, Mravak-Stipetic M, Jukic S, Kleinheinz J, Lukac J. Salivary levels of vascular endothelial growth factor (VEGF) in recurrent aphthous ulceration. J Oral Pathol Med 2002;31:106-108. [PubMed: 11896832]

97. Aikou T, Shimazu H. Difference in main lymphatic pathways from the lower esophagus and gastric cardia. Jpn J Surg 1989;19:290-295. [PubMed: 2779027]

98. Auvinen MI, Sihvo EI, Ruohtula T, Salminen JT, Koivistoinen A, Siivola P, Ronnholm R, Ramo JO, Bergman M, Salo JA. Incipient angiogenesis in Barrett's epithelium and lymphangiogenesis in Barrett's adenocarcinoma. J Clin Oncol 2002;20:2971-2979. [PubMed: 12089227]

99. Nagata H, Guth PH. In vivo observation of the lymphatic system in the rat stomach. Gastroenterology 1984;86:1443-1450. [PubMed: 6425104]

100. Ji RC, Kato S. Enzyme-histochemical study on postnatal development of rat stomach lymphatic vessels. Microvasc Res 1997;54:1-12. [PubMed: 9245639]

101. Goldman H, Antonioli DA. Mucosal biopsy of the esophagus, stomach, and proximal duodenum. Hum Pathol 1982;13:423-448. [PubMed: 7076225]

102. Lehnert T, Erlandson RA, DeCosse JJ. Lymph and blood capillaries of the human gastric mucosa. A morphologic basis for metastasis in early gastric carcinoma. Gastroenterology 1985;89:939_ 950. [PubMed: 4043674]

103. Listrom MB, Fenoglio-Preiser CM. Lymphatic distribution of the stomach in normal, inflammatory, hyperplastic, and neoplastic tissue. Gastroenterology 1987;93:506-514. [PubMed: 3301516]

104. Casley-Smith JR. Endothelial fenestrae in intestinal villi: differences between the arterial and venous ends of the capillaries. Microvasc Res 1971;3:49-68. [PubMed: 5092927]

105. Clementi F, Palade GE. Intestinal capillaries. I. Permeability to peroxidase and ferritin. J Cell Biol 1969;41:33-58. [PubMed: 5775791] 
106. Kalima TV. Ultrastructure of the intestinal lymphatics in regard to absorption. Scand J Gastroenterol 1973;8:193-196. [PubMed: 4579678]

107. Tso P, Balint JA. Formation and transport of chylomicrons by enterocytes to the lymphatics. Am J Physiol 1986;250:G715-G726. [PubMed: 3521320]

108. Kim KE, Sung HK, Koh GY. Lymphatic development in mouse small intestine. Dev Dyn 2007;236:2020-2025. [PubMed: 17576138]

109. Gale NW, Prevo R, Espinosa J, Ferguson DJ, Dominguez MG, Yancopoulos GD, Thurston G, Jackson DG. Normal lymphatic development and function in mice deficient for the lymphatic hyaluronan receptor LYVE-1. Mol Cell Biol 2007;27:595-604. [PubMed: 17101772]

110. Crissinger KD, Kvietys PR, Granger DN. Pathophysiology of gastrointestinal mucosal permeability. J Intern Med Suppl 1990;732:145-154. [PubMed: 2200413]

111. Benoit, JN.; Zawieja, DC. Physiology of the gastrointestinal tract. In: Johnson, LR.; Alpers, DH.; Christensen, J.; Jacobson, ED.; Walsh, JH., editors. Gastrointestinal Lymphatics. New York: Raven Press; 1994. p. 1669-1692.

112. Kvietys PR, Miller T, Granger DN. Intrinsic control of colonic blood flow and oxygenation. Am J Physiol 1980;238:G478-G484. [PubMed: 7386631]

113. Fukushima K, Sasaki I, Masuda T, Nagura H, Naito H, Funayama Y, Matsuno S. Threedimensional structure of mucosal and submucosal lymphatics in rat small intestine. Tohoku J Exp Med 1998;185:9-14. [PubMed: 9710940]

114. Ohtani O. Three-dimensional organization of lymphatics and its relationship to blood vessels in rat small intestine. Cell Tissue Res 1987;248:365-374. [PubMed: 3581150]

115. Lee JS, Duncan KM. Lymphatic and venous transport of water from rat jejunum: a vascular perfusion study. Gastroenterology 1968;54:559-567. [PubMed: 5652508]

116. Kamei Y. The distribution and relative location of the lymphatic and blood vessels in the mucosa of the rabbit colon. Nagoya Med J 1969;15:223-238. [PubMed: 5373049]

117. Hirashima T, Kuwahara D, Nishi M. Morphology of lymphatics in the canine large intestine. Lymphology 1984;17:69-72. [PubMed: 6471918]

118. Hirai T, Nimura Y, Sakai H. The three-dimensional microstructure of intramural lymphatics in the canine large intestine. Gastroenterol Jpn 1990;25:169-174. [PubMed: 2347470]

119. Courtice, FC.; Yoffey, JM. The formation of lymph in lymphatics, lymph and the lymphomyeloid complex. London: Academic Press; 1970. p. 123-132.

120. Kalima TV, Collan Y. Intestinal villus in experimental lymphatic obstruction. Correlation of light and electron microscopic findings with clinical diseases. Scand J Gastroenterol 1970;5:497-510. [PubMed: 5460412]

121. Kalima TV. Experimental lymphatic obstruction in the ileum. Ann Chir Gynaecol Fenn 1970;59:187-201. [PubMed: 5491558]

122. Kalima TV, Peltokallio P, Myllarniemi H. Vascular pattern in ileal Crohn's disease. Ann Clin Res 1975;7:23-31. [PubMed: 1155908]

123. Kalima TV, Saloniemi H, Rahko T. Experimental regional enteritis in pigs. Scand J Gastroenterol 1976;11:353-362. [PubMed: 935796]

124. Aepfelbacher M, Trasak C, Ruckdeschel K. Effector functions of pathogenic Yersinia species. Thromb Haemost 2007;98:521-529. [PubMed: 17849040]

125. Cole WR, Witte MH, Witte CL. Lymph culture: a new tool for the investigation of human infections. Ann Surg 1969;170:705-714. [PubMed: 5344035]

126. Spahn TW, Muller MK, Domschke W, Kucharzik T. Role of lymphotoxins in the development of Peyer's patches and mesenteric lymph nodes: relevance to intestinal inflammation and treatment. Ann N Y Acad Sci 2006;1072:187-193. [PubMed: 17057199]

127. Ohtani O, Ohtani Y. Structure and function of rat lymph nodes. Arch Histol Cytol 2008;71:69-76. [PubMed: 18974599]

128. Ritchie HD, Grindlay JH, Bollman JL. Flow of lymph from the canine liver. Am J Physiol 1959;196:105-109. [PubMed: 13617445]

129. Comparini L. Lymph vessels of the liver in man. Microscopic morphology and histotopography. Angiologica 1969;6:262-274. [PubMed: 5344346] 
130. Heath T, Lowden S. Pathways of interstitial fluid and lymph flow in the liver acinus of the sheep and mouse. J Anat 1998;192(Pt 3):351-358. [PubMed: 9688501]

131. Henriksen JH, Lassen NA. Pressure profile in liver sinusoids. A model of localization of sinusoidal resistance in the normal and cirrhotic liver. Liver 1988;8:88-94. [PubMed: 3367712]

132. Burke Z, Oliver G. Prox 1 is an early specific marker for the developing liver and pancreas in the mammalian foregut endoderm. Mech Dev 2002;118:147-155. [PubMed: 12351178]

133. Sosa-Pineda B, Wigle JT, Oliver G. Hepatocyte migration during liver development requires Prox1. Nat Genet 2000;25:254-255. [PubMed: 10888866]

134. Nagahashi M, Shirai Y, Wakai T, Sakata J, Ajioka Y, Hatakeyama K. Perimuscular connective tissue contains more and larger lymphatic vessels than the shallower layers in human gallbladders. World J Gastroenterol 2007;13:4480-4483. [PubMed: 17724804]

135. Weiner S, Gramatica L, Voegle LD, Hauman RL, Anderson MC. Role of the lymphatic system in the pathogenesis of inflammatory disease in the biliary tract and pancreas. Am J Surg 1970;119:55-61. [PubMed: 5411669]

136. Pissas A. Clinical and surgical anatomy of the lymphatic circulation of pancreas. J Chir (Paris) 1984;121:557-571. [PubMed: 6511823]

137. O'Morchoe CC. Lymphatic system of the pancreas. Microsc Res Tech 1997;37:456-477. [PubMed: 9220424]

138. Rusznyak I, FMSG. Lymphatics and Lymph Circulation Physiology and Pathology. London: Pergamon Press; 1967. p. 100100-118

139. Reynolds BM. Observations of subcapsular lymphatics in normal and diseased human pancreas. Ann Surg 1970;171:559-566. [PubMed: 5436124]

140. Wang J, Kilic G, Aydin M, Burke Z, Oliver G, Sosa-Pineda B. Prox1 activity controls pancreas morphogenesis and participates in the production of "secondary transition" pancreatic endocrine cells. Dev Biol 2005;286:182-194. [PubMed: 16122728]

141. Schneider M, Buchler P, Giese N, Giese T, Wilting J, Buchler MW, Friess H. Role of lymphangiogenesis and lymphangiogenic factors during pancreatic cancer progression and lymphatic spread. Int J Oncol 2006;28:883-890. [PubMed: 16525637]

142. Mayer AD, Airey M, Hodgson J, McMahon MJ. Enzyme transfer from pancreas to plasma during acute pancreatitis. The contribution of ascitic fluid and lymphatic drainage of the pancreas. Gut 1985;26:876-881. [PubMed: 2411638]

143. Rasio EA, Hampers CL, Soeldner JS, Cahill GF Jr. Diffusion of glucose, insulin, inulin, and Evans blue protein into thoracic duct lymph of man. J Clin Invest 1967;46:903-910. [PubMed: 6026096]

144. Mortimore GE, Tietze F. Studies on the fate of insulin-I131 in the perfused rat liver. Metabolism 1959;8:479-480. [PubMed: 13666394]

145. Waldmann TA, Steinfeld JL, Dutcher TF, Davidson JD, Gordon RS Jr. The role of the gastrointestinal system in "idiopathic hypoproteinemia". Gastroenterology 1968;54 Suppl-6

146. Vignes S, Bellanger J. Primary intestinal lymphangiectasia (Waldmann's disease). Orphanet J Rare Dis 2008;3:5. [PubMed: 18294365]

147. Boursier V, Vignes S. Limb lymphedema as a first manifestation of primary intestinal lymphangiectasia (Waldmann's disease). J Mal Vasc 2004;29:103-106. [PubMed: 15229406]

148. Van SW. Alpha 1-antitrypsin deficiency: an overview. Acta Clin Belg 1993;48:171-189. [PubMed: 8396299]

149. Becker K, Berger M, Niederau C, Frieling T. Individual fecal alpha 1-antitrypsin excretion reflects clinical activity in Crohn's disease but not in ulcerative colitis. Hepatogastroenterology 1999;46:2309-2314. [PubMed: 10521988]

150. Hokari R, Kitagawa N, Watanabe C, Komoto S, Kurihara C, Okada Y, Kawaguchi A, Nagao S, Hibi T, Miura S. Changes in regulatory molecules for lymphangiogenesis in intestinal lymphangiectasia with enteric protein loss. J Gastroenterol Hepatol 2008;23:e88-e95. [PubMed: 18005011]

151. Hardikar W, Smith AL, Chow CW. Neonatal protein-losing enteropathy caused by intestinal lymphatic hypoplasia in siblings. J Pediatr Gastroenterol Nutr 1997;25:217-221. [PubMed: 9252912] 
152. Zeng Y, Wang F, Williams ED, Chow CW. Lymphatics in the alimentary tract of children in health and disease: study on mucosal biopsies using the monoclonal antibody d2-40. Pediatr Dev Pathol 2005;8:541-549. [PubMed: 16211456]

153. Stormon MO, Mitchell JD, Smoleniec JS, Tobias V, Day AS. Congenital intestinal lymphatic hypoplasia presenting as non-immune hydrops in utero, and subsequent neonatal protein-losing enteropathy. J Pediatr Gastroenterol Nutr 2002;35:691-694. [PubMed: 12454588]

154. Milroy WF. An underscribed variety of hereditary edema. New York Medical Journal 1892:505508.

155. Irrthum A, Karkkainen MJ, Devriendt K, Alitalo K, Vikkula M. Congenital hereditary lymphedema caused by a mutation that inactivates VEGFR3 tyrosine kinase. Am J Hum Genet 2000;67:295-301. [PubMed: 10856194]

156. Hong SE, Shugart YY, Huang DT, Shahwan SA, Grant PE, Hourihane JO, Martin ND, Walsh CA. Autosomal recessive lissencephaly with cerebellar hypoplasia is associated with human RELN mutations. Nat Genet 2000;26:93-96. [PubMed: 10973257]

157. Rezaie T, Ghoroghchian R, Bell R, Brice G, Hasan A, Burnand K, Vernon S, Mansour S, Mortimer P, Jeffery S, Child A, Sarfarazi M. Primary non-syndromic lymphoedema (Meige disease) is not caused by mutations in FOXC2. Eur J Hum Genet 2008;16:300-304. [PubMed: 18197197]

158. Kriederman BM, Myloyde TL, Witte MH, Dagenais SL, Witte CL, Rennels M, Bernas MJ, Lynch MT, Erickson RP, Caulder MS, Miura N, Jackson D, Brooks BP, Glover TW. FOXC2 haploinsufficient mice are a model for human autosomal dominant lymphedema-distichiasis syndrome. Hum Mol Genet 2003;12:1179-1185. [PubMed: 12719382]

159. Brice G, Mansour S, Bell R, Collin JR, Child AH, Brady AF, Sarfarazi M, Burnand KG, Jeffery $\mathrm{S}$, Mortimer P, Murday VA. Analysis of the phenotypic abnormalities in lymphoedemadistichiasis syndrome in 74 patients with FOXC2 mutations or linkage to 16q24. J Med Genet 2002;39:478-483. [PubMed: 12114478]

160. Hennekam RC, Geerdink RA, Hamel BC, Hennekam FA, Kraus P, Rammeloo JA, Tillemans AA. Autosomal recessive intestinal lymphangiectasia and lymphedema, with facial anomalies and mental retardation. Am J Med Genet 1989;34:593-600. [PubMed: 2624276]

161. Pochapin, MB. Protein losing disorders of the gastrointestinal tract. In: Brandt, LJ., editor. Clinical practice of gastroenterology. Philadelphia Churchill Livingstone; 1999. p. 476-483.

162. Davidson JD, Waldmann TA, Goodman DS, Gordon RS Jr. Protein-losing gastroenteropathy in congestive heart-failure. Lancet 1961;1:899-902. [PubMed: 13720056]

163. Kaihara S, Nishimura H, Oyagi T, Kameda H, Ueda H. Protein-losing gastroenteropathys as a cause of hypoproteinemia in constrictive pericarditis. Jpn Heart J 1963;185:386-394. [PubMed: 14045588]

164. Doelle W, Martini GA, Petersen F. Idiopathic familial cardiomegaly with intermittent gastrointestinal protein loss. Dtsch Med Wochenschr 1962;87:1333-1338. [PubMed: 13886895]

165. Davidson JD, Waldmann TA, Goodman DS, Gordon RS Jr. Protein-losing gastroenteropathy in congestive heart-failure. Lancet 1961;1:899-902. [PubMed: 13720056]

166. Stalder H, Joliat G. Blood in the lymph (hemochylia) and intestinal lymphangiectasia associated with Lutembacher's syndrome. Am J Med 1973;55:99-105. [PubMed: 4715935]

167. Jeejeebhoy KN. Cause of hypoalbuminaemia in patients with gastrointestinal and cardiac disease. Lancet 1962;1:343-348. [PubMed: 14451501]

168. Meadows J, Gauvreau K, Jenkins K. Lymphatic obstruction and protein-losing enteropathy in patients with congenital heart disease. Congenit Heart Dis 2008;3:269-276. [PubMed: 18715461]

169. Rychik J. Protein-losing enteropathy after Fontan operation. Congenit Heart Dis 2007;2:288-300. [PubMed: 18377444]

170. Aagenaes O, van der Hagen CB, Refsum S. Hereditary recurrent intrahepatic cholestasis from birth. Arch Dis Child 1968;43:646-657. [PubMed: 5702224]

171. Ferrell RE, Finegold DN. Research perspectives in inherited lymphatic disease: an update. Ann N Y Acad Sci 2008;1131:134-139. [PubMed: 18519966]

172. van, dB; I. Noonan syndrome. Orphanet J Rare Dis 2007;2:4. [PubMed: 17222357] 
173. Malek NP, Ocran K, Tietge UJ, Maschek H, Gratz KF, Trautwein C, Wagner S, Manns MP. A case of the yellow nail syndrome associated with massive chylous ascites, pleural and pericardial effusions. Z Gastroenterol 1996;34:763-766. [PubMed: 8956479]

174. Hoque SR, Mansour S, Mortimer PS. Yellow nail syndrome: not a genetic disorder? Eleven new cases and a review of the literature. Br J Dermatol 2007;156:1230-1234. [PubMed: 17459037]

175. Pullinger BD FH. Some observations on the structure and functions of lymphatics: their behavior in local edema. Br J Exp Pathol 1935;16:49.

176. Van Kruiningen HJ, Colombel JF. The forgotten role of lymphangitis in Crohn's disease. Gut 2008;57:1-4. [PubMed: 18094195]

177. Colombel JF, Watson AJ, Neurath MF. The 10 remaining mysteries of inflammatory bowel disease. Gut 2008;57:429-433. [PubMed: 18079284]

178. Kaiserling E, Krober S, Geleff S. Lymphatic vessels in the colonic mucosa in ulcerative colitis. Lymphology 2003;36:52-61. [PubMed: 12926829]

179. Geleff S, Schoppmann SF, Oberhuber G. Increase in podoplanin-expressing intestinal lymphatic vessels in inflammatory bowel disease. Virchows Arch 2003;442:231-237. [PubMed: 12647212]

180. Tonelli P. New development in Crohn's disease: ++unravelling the mystery and its reinstatement as a surgically treatable condition. Part 2. Potential etiopathogenesis of "terminal ileitis" and extension of the disease to mesenteric small intestine and the colon. Chir Ital 2000;52:243-250. [PubMed: 10932368]

181. Chan AK, Vergnolle N, Hollenberg MD, von der Weid PY. Proteinase-activated receptor 2 activation modulates guinea-pig mesenteric lymphatic vessel pacemaker potential and contractile activity. J Physiol 2004;560:563-576. [PubMed: 15331674]

182. Drake RE, Teague RA, Gabel JC. Lymphatic drainage reduces intestinal edema and fluid loss. Lymphology 1998;31:68-73. [PubMed: 9664271]

183. Pullman WE, Elsbury S, Kobayashi M, Hapel AJ, Doe WF. Enhanced mucosal cytokine production in inflammatory bowel disease. Gastroenterology 1992;102:529-537. [PubMed: 1370662]

184. Al-Rawi MA, Watkins G, Mansel RE, Jiang WG. The effects of interleukin-7 on the lymphangiogenic properties of human endothelial cells. Int J Oncol 2005;27:721-730. [PubMed: 16077922]

185. Al-Rawi MA, Watkins G, Mansel RE, Jiang WG. Interleukin 7 upregulates vascular endothelial growth factor $\mathrm{D}$ in breast cancer cells and induces lymphangiogenesis in vivo. Br J Surg 2005;92:305-310. [PubMed: 15672426]

186. Kader HA, Tchernev VT, Satyaraj E, Lejnine S, Kotler G, Kingsmore SF, Patel DD. Protein microarray analysis of disease activity in pediatric inflammatory bowel disease demonstrates elevated serum PLGF, IL-7, TGF-beta1, and IL-12p40 levels in Crohn's disease and ulcerative colitis patients in remission versus active disease. Am J Gastroenterol 2005;100:414-423. [PubMed: 15667502]

187. Johnson LA, Prevo R, Clasper S, Jackson DG. Inflammation-induced uptake and degradation of the lymphatic endothelial hyaluronan receptor LYVE-1. J Biol Chem 2007;282:33671-33680. [PubMed: 17884820]

188. Zhang Q, Lu Y, Proulx ST, Guo R, Yao Z, Schwarz EM, Boyce BF, Xing L. Increased lymphangiogenesis in joints of mice with inflammatory arthritis. Arthritis Res Ther 2007;9:R118. [PubMed: 17997858]

189. Polzer K, Baeten D, Soleiman A, Distler J, Gerlag DM, Tak PP, Schett G, Zwerina J. Tumour necrosis factor blockade increases lymphangiogenesis in murine and human arthritic joints. Ann Rheum Dis 2008;67:1610-1616. [PubMed: 18174217]

190. Hatoum OA, Spinelli KS, bu-Hajir M, Attila T, Franco J, Otterson MF, Telford GL, Binion DG. Mesenteric venous thrombosis in inflammatory bowel disease. J Clin Gastroenterol 2005;39:2731. [PubMed: 15599206]

191. Servelle M, Turiaf J, beaux-Fernet M, Laroche C, Bernier JJ, Soulie J, Bacourt F, Chabot J, Fournier D, Andrieux JB. Sclerosis of the intestinal lymphatic vessels. Sem Hop 1975;51:799806. [PubMed: 164689] 
192. Fish JC, McNeel L, Holaday WJ. Lymphatic obstruction in the pathogenesis of intestinal mucosal atrophy. Ann Surg 1969;169:316-325. [PubMed: 5380857]

193. Miura S, Asakura H, Tsuchiya M. Lymphatic abnormalities in protein-losing gastropathy, especially in Menetrier's disease. Angiology 1981;32:345-354. [PubMed: 7235306]

194. Konstantinidou AE, Morphopoulos G, Korkolopoulou P, Eftychiadis C, Stamokosta E, Saetta A, Agapitos E. Menetrier disease of early infancy: a separate entity? J Pediatr Gastroenterol Nutr 2004;39:177-182. [PubMed: 15269624]

195. Sferra TJ, Pawel BR, Qualman SJ, Li BU. Menetrier disease of childhood: role of cytomegalovirus and transforming growth factor alpha. J Pediatr 1996;128:213-219. [PubMed: 8636814]

196. Kinoshita A, Odagi I, Aoki Y, Hirohama K, Ishiguro H, Nikami T, Tamaki S, Searashi Y, Sudou S, Hokari A, Ishikawa T, Negishi M, Nishino H, Tajiri H, Ikegami M. Case of lymphangioleiomyomatosis associated with protein-losing gastroenteropathy. Nippon Shokakibyo Gakkai Zasshi 2008;105:1775-1780. [PubMed: 19057163]

197. Kochnev OS, Sharafislamov FS. Thoracic duct lymph in acute pancreatitis. Biull Eksp Biol Med 1971;71:31-33. [PubMed: 5563782]

198. Dupont JM, Litvine J. Lymphatic factors in experimental pancreatitis. Acta Chir Belg 1964;63:687-697. [PubMed: 14227868]

199. Penn AH, Hugli TE, Schmid-Schonbein GW. Pancreatic enzymes generate cytotoxic mediators in the intestine. Shock 2007;27:296-304. [PubMed: 17304111]

200. Qu P, Ji RC, Kato S. Histochemical analysis of lymphatic endothelial cells in the pancreas of nonobese diabetic mice. J Anat 2003;203:523-530. [PubMed: 14635805]

201. Brzek V, Bartos V. Therapeutic effect of the prolonged thoracic duct lymph fistula in patients with acute pancreatitis. Digestion 1969;2:43-50. [PubMed: 5776466]

202. Montravers P, Chollet-Martin S, Marmuse JP, Gougerot-Pocidalo MA, Desmonts JM. Lymphatic release of cytokines during acute lung injury complicating severe pancreatitis. Am J Respir Crit Care Med 1995;152:1527-1533. [PubMed: 7582288]

203. Deitch EA. Role of the gut lymphatic system in multiple organ failure. Curr Opin Crit Care 2001;7:92-98. [PubMed: 11373517]

204. Adams CA Jr, Sambol JT, Xu DZ, Lu Q, Granger DN, Deitch EA. Hemorrhagic shock induced up-regulation of P-selectin expression is mediated by factors in mesenteric lymph and blunted by mesenteric lymph duct interruption. J Trauma 2001;51:625-631. [PubMed: 11586150]

205. Sambol JT, Lee MA, Caputo FJ, Kawai K, Badami C, Kawai T, Deitch EA, Yatani A. Mesenteric lymph duct ligation prevents trauma/hemorrhage shock-induced cardiac contractile dysfunction. J Appl Physiol 2009;106:57-65. [PubMed: 19008486]

206. Badami CD, Senthil M, Caputo FJ, Rupani BJ, Doucet D, Pisarenko V, Xu DZ, Lu Q, Feinman R, Deitch EA. Mesenteric lymph duct ligation improves survival in a lethal shock model. Shock 2008;30:680-685. [PubMed: 18496238]

207. Deitch EA, Feketeova E, Adams JM, Forsythe RM, Xu DZ, Itagaki K, Redl H. Lymph from a primate baboon trauma hemorrhagic shock model activates human neutrophils. Shock 2006;25:460-463. [PubMed: 16680010]

208. Adams CA Jr, Xu DZ, Lu Q, Deitch EA. Factors larger than 100 kd in post-hemorrhagic shock mesenteric lymph are toxic for endothelial cells. Surgery 2001;129:351-363. [PubMed: 11231464]

209. Cavriani G, Domingos HV, Oliveira-Filho RM, Sudo-Hayashi LS, Vargaftig BB, de Lima WT. Lymphatic thoracic duct ligation modulates the serum levels of IL-1beta and IL-10 after intestinal ischemia/reperfusion in rats with the involvement of tumor necrosis factor alpha and nitric oxide. Shock 2007;27:209-213. [PubMed: 17224798]

210. Guo W, Magnotti LJ, Ding J, Huang Q, Xu D, Deitch EA. Influence of gut microflora on mesenteric lymph cytokine production in rats with hemorrhagic shock. J Trauma 2002;52:11781185. [PubMed: 12045650]

211. Coelho FR, Cavriani G, Soares AL, Teixeira SA, Almeida PC, Sudo-Hayashi LS, Muscara MN, Oliveira-Filho RM, Vargaftig BB, Tavares-de-Lima W. Lymphatic-borne IL-1beta and the 
inducible isoform of nitric oxide synthase trigger the bronchial hyporesponsiveness after intestinal ischema/reperfusion in rats. Shock 2007;28:694-699. [PubMed: 17607157]

212. Magnotti LJ, Upperman JS, Xu DZ, Lu Q, Deitch EA. Gut-derived mesenteric lymph but not portal blood increases endothelial cell permeability and promotes lung injury after hemorrhagic shock. Ann Surg 1998;228:518-527. [PubMed: 9790341]

213. Haltinner K, Nigg C, Kolyvanos NU, Kaser L, Vetter W. Whipple's disease/Morbus Whipple. Main symptoms: fever, lymphadenopathy, arthralgia, weight loss, chronic diarrhea. Praxis (Bern 1994 ) 2006;95:3-10. [PubMed: 16445131]

214. Bruggemann A, Burchardt H, Lepsien G. Sonographical findings in Whipple's disease. A case report with regard to the literature. Surg Endosc 1992;6:138-140. [PubMed: 1380187]

215. Tesler MA, Witte MH, Becker FF, Dumont AE. Whipple's disease: Identification of circulating Whipple cells in thoracic duct lymph. Gastroenterology 1965;48:110-117. [PubMed: 14252744]

216. Witte MH, Horowitz L, Dumont AE. Use of thoracic-duct cannulation in the diagnosis of tuberculous enteritis. N Engl J Med 1963;268:1125-1126. [PubMed: 14001395]

217. Witte MH, Dumont AE, Cole WR, Witte CL, Kintner K. Lymph circulation in hepatic cirrhosis: effect of portacaval shunt. Ann Intern Med 1969;70:303-310. [PubMed: 5764506]

218. Witte MH, Witte CL, Dumont AE. Progress in liver disease: physiological factors involved in the causation of cirrhotic ascites. Gastroenterology 1971;61:742-750. [PubMed: 5117639]

219. Stewart RH, Laine GA. Flow in lymphatic networks: interaction between hepatic and intestinal lymph vessels. Microcirculation 2001;8:221-227. [PubMed: 11528530]

220. Witte MH, Witte CL, Dumont AE. Estimated net transcapillary water and protein flux in the liver and intestine of patients with portal hypertension from hepatic cirrhosis. Gastroenterology 1981;80:265-272. [PubMed: 7450417]

221. Ando T, Jordan PA, Wang Y, Jennings MH, Harper MH, Houghton J, Elrod J, Alexander JS. Homogeneity of mesothelial cells with lymphatic endothelium: expression of lymphatic endothelial markers by mesothelial cells. Lymphat Res Biol 2005;3:117-125. [PubMed: 16190816]

222. Witte CL, Witte MH. On the causation of edema: a lymphologic perspective. Perspect Biol Med 1997;41:86-97. [PubMed: 9394475]

223. Garcia-Carrasco M, Ramos-Casals M, Cervera R, Font J. Primary Sjogren's syndrome and lymphatic proliferation. Med Clin (Barc) 2000;114:740-746. [PubMed: 10919130]

224. Claeys V, Wackens G. Sjogren syndrome: a review of the literature and a case report. Rev Belge Med Dent 2006;61:161-172. [PubMed: 17408137]

225. Altorki NK, Zhou XK, Stiles B, Port JL, Paul S, Lee PC, Mazumdar M. Total number of resected lymph nodes predicts survival in esophageal cancer. Ann Surg 2008;248:221-226. [PubMed: 18650631]

226. Yamagata K, Kumagai K, Shimizu K, Masuo K, Nishida Y, Yasui A. Gastrointestinal cancer metastasis and lymphogenous spread: viewpoint of animal models of lymphatic obstruction. Jpn J Clin Oncol 1998;28:104-106. [PubMed: 9544824]

227. Yonemura Y, Fushida S, Bando E, Kinoshita K, Miwa K, Endo Y, Sugiyama K, Partanen T, Yamamoto H, Sasaki T. Lymphangiogenesis and the vascular endothelial growth factor receptor (VEGFR)-3 in gastric cancer. Eur J Cancer 2001;37:918-923. [PubMed: 11313181]

228. Saad RS, Kordunsky L, Liu YL, Denning KL, Kandil HA, Silverman JF. Lymphatic microvessel density as prognostic marker in colorectal cancer. Mod Pathol 2006;19:1317-1323. [PubMed: 16799477]

229. Jin G, Sugiyama M, Tuo H, Oki A, Abe N, Mori T, Masaki T, Fujioka Y, Atomi Y. Distribution of lymphatic vessels in the neural plexuses surrounding the superior mesenteric artery. Pancreas 2006;32:62-66. [PubMed: 16340746]

230. Duxbury MS, Grikscheit TC, Gardner-Thorpe J, Rocha FG, Ito H, Perez A, Ashley SW, Vacanti JP, Whang EE. Lymphangiogenesis in tissue-engineered small intestine. Transplantation 2004;77:1162-1166. [PubMed: 15114078]

231. Kellersman R, Zhong R, Kiyochi H, Garcia B, Grant DR. Reconstruction of the intestinal lymphatic drainage after small bowel transplantation. Transplantation 2000;69:10-16. [PubMed: 10653372] 
232. Marincek B, Barbier PA, Becker CD, Mettler D, Ruchti C. CT appearance of impaired lymphatic drainage in liver transplants. AJR Am J Roentgenol 1986;147:519-523. [PubMed: 3526841]

233. Ferrell RE, Kimak MA, Lawrence EC, Finegold DN. Candidate gene analysis in primary lymphedema. Lymphat Res Biol 2008;6:69-76. [PubMed: 18564921]

234. Hosking BM, Wang SC, Downes M, Koopman P, Muscat GE. The VCAM-1 gene that encodes the vascular cell adhesion molecule is a target of the Sry-related high mobility group box gene, Sox18. J Biol Chem 2004;279:5314-5322. [PubMed: 14634005]

235. Danussi C, Spessotto P, Petrucco A, Wassermann B, Sabatelli P, Montesi M, Doliana R, Bressan GM, Colombatti A. Emilin1 deficiency causes structural and functional defects of lymphatic vasculature. Mol Cell Biol 2008;28:4026-4039. [PubMed: 18411305]

236. Doliana R, Bot S, Bonaldo P, Colombatti A. EMI, a novel cysteine-rich domain of EMILINs and other extracellular proteins, interacts with the $\mathrm{gClq}$ domains and participates in multimerization. FEBS Lett 2000;484:164-168. [PubMed: 11068053]

237. Dellinger MT, Hunter RJ, Bernas MJ, Witte MH, Erickson RP. Chy-3 mice are Vegfc haploinsufficient and exhibit defective dermal superficial to deep lymphatic transition and dermal lymphatic hypoplasia. Dev Dyn 2007;236:2346-2355. [PubMed: 17584866]

238. Shimoda H, Kato S. A model for lymphatic regeneration in tissue repair of the intestinal muscle coat. Int Rev Cytol 2006;250:73-108. [PubMed: 16861064]

239. Fang J, Dagenais SL, Erickson RP, Arlt MF, Glynn MW, Gorski JL, Seaver LH, Glover TW. Mutations in FOXC2 (MFH-1), a forkhead family transcription factor, are responsible for the hereditary lymphedema-distichiasis syndrome. Am J Hum Genet 2000;67:1382-1388. [PubMed: 11078474]

240. Finegold DN, Kimak MA, Lawrence EC, Levinson KL, Cherniske EM, Pober BR, Dunlap JW, Ferrell RE. Truncating mutations in FOXC2 cause multiple lymphedema syndromes. Hum Mol Genet 2001;10:1185-1189. [PubMed: 11371511]

241. Cederberg A, Gronning LM, Ahren B, Tasken K, Carlsson P, Enerback S. FOXC2 is a winged helix gene that counteracts obesity, hypertriglyceridemia, and diet-induced insulin resistance. Cell 2001;106:563-573. [PubMed: 11551504]

242. Cederberg A, Grande M, Rhedin M, Peng XR, Enerback S. In vitro differentiated adipocytes from a Foxc2 reporter knock-in mouse as screening tool. Transgenic Res. 2009

243. Salas S, Stock N, Stoeckle E, Kind M, Bui B, Coindre JM. Chronic lymphedema due to morbid obesity: an exceptional cause of abdominal wall angiosarcoma. Virchows Arch 2008;453:217219. [PubMed: 18560886]

244. Brorson H, Ohlin K, Olsson G, Langstrom G, Wiklund I, Svensson H. Quality of life following liposuction and conservative treatment of arm lymphedema. Lymphology 2006;39:8-25. [PubMed: 16724506]

245. Silha JV, Krsek M, Sucharda P, Murphy LJ. Angiogenic factors are elevated in overweight and obese individuals. Int J Obes (Lond) 2005;29:1308-1314. [PubMed: 15953938]

246. Sandek A, Rauchhaus M, Anker SD, von HS. The emerging role of the gut in chronic heart failure. Curr Opin Clin Nutr Metab Care 2008;11:632-639. [PubMed: 18685461] 


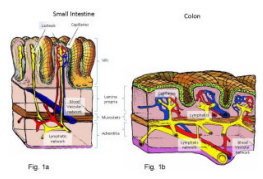

Figure 1.

a) Small intestine lymphatics. Small intestinal villous lacteals in the center of each villus, b) large intestine lymphatics. Large intestine lacks lymphatic lacteals but is supplied with lymphatic vessels. 


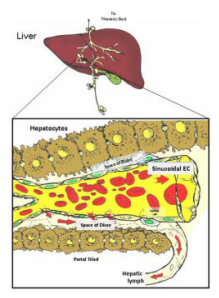

Figure 2.

Lymphatics in liver. Lymph filtered into the space of Disse (peri-sinusoidal) drains to deep lymphatics in the hepatic parenchyma associated with portal triads. 


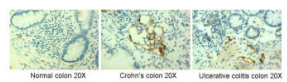

Figure 3.

Enhanced lymphatics in IBD. Increased lymphatic abundance (D2-40+ staining) is seen in Crohn's disease (panel 2) and ulcerative colitis (panel 3), compared to normal controls (panel 1). 